\title{
SLCA/IP Power Alternative Screening Method (SPASM)
}

Decision and Information Sciences Division

Argonne National Laboratory

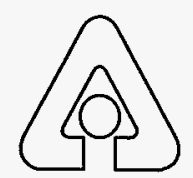

Operated by The University of Chicago, under Contract W-31-109-Eng-38, for the

United States Department of Energy 


\section{Argonne National Laboratory}

Argonne National Laboratory, with facilities in the states of Illinois and Idaho, is owned by the United States Government, and operated by the University of Chicago under the provisions of a contract with the Department of Energy.

This technical memo is a product of Argonne's Decision and Information Sciences (DIS) Division. For information on the division's scientific and engineering activities, contact:

Director, Decision and Information Sciences Division

Argonne National Laboratory

Argonne, Ilinois 60439-4815

Telephone (708) 252-5464

Presented in this technical memo are preliminary results of ongoing work or work that is more limited in scope and depth than that described in formal reports issued by the DIS Division.

Publishing support services were provided by Argonne's Information and Publishing Division (for more information, see IPD's home page: http://www.ipd.anl.gov/).

\section{Disclaimer}

This report was prepared as an account of work sponsored by an agency of the United States Govemment. Neither the United States Government nor any agency thereof, nor any of their employees, makes any warranty, express or implied, or assumes any legal liability or responsibility for the accuracy, completeness, or usefulness of any information, apparatus, product, or process disclosed, or represents that its use would not infringe privately owned rights. Reference herein to any specific commercial product, process, or service by trade name, trademark, manufacturer, or otherwise, does not necessarily constitute or imply its endorsement, recommendation, or favoring by the United States Government or any agency thereof. The views and opinions of authors expressed herein do not necessarily state or reflect those of the United States Government or any agency thereof. 


\section{SLCA/IP Power Alternative Screening Method (SPASM)}

by S.C. Palmer* and J.D. Ancrile

Policy and Economic Analysis Group,

Decision and Information Sciences Division,

Argonne National Laboratory, 9700 South Cass Avenue, Argonne, Illinois 60439

March 1995

Work sponsored by United States Department of Energy, Western Area Power Administration

* Palmer is affiliated with Western Area Power Administration.

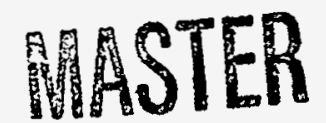


This report is printed on recycled paper. 


\section{FOREWORD}

This report is one of a series of technical memorandums prepared to support an environmental impact statement (EIS) on power marketing prepared by Argonne National Laboratory for the U.S. Department of Energy's Western Area Power Administration (Western). Western markets electricity produced at hydroelectric facilities operated by the Bureau of Reclamation. The facilities are known collectively as the Salt Lake City Area Integrated Projects (SLCA/IP) and include dams equipped for power generation on the Colorado, Green, Gunnison, and Rio Grande rivers and on Plateau Creek in the states of Arizona, Colorado, New Mexico, Utah, and Wyoming.

Western proposes to establish a level of commitment (sales) of long-term firm electrical capacity and energy from the SLCA/IP hydroelectric power plants; the impacts of this proposed action are evaluated in the EIS. Of the SLCA/IP facilities, only the Glen Canyon Dam, Flaming Gorge Dam, and Aspinall Unit (which includes Blue Mesa, Morrow Point, and Crystal dams) are influenced by Western's power scheduling and transmission decisions. For this reason, the impacts of hydropower operations at these three facilities were examined in the EIS.

The technical memorandums present detailed findings of studies conducted by Argonne National Laboratory specifically for the EIS. These studies are summarized in the EIS, and the results were used to assess environmental impacts related to alternative commitment levels. Technical memorandums were prepared on a number of socioeconomic and natural resource topics. Staff members of Argonne National Laboratory's Decision and Information Sciences Division and Environmental Assessment Division prepared these technical memorandums and the EIS as part of a joint effort managed by the Environmental Assessment Division. 


\section{CONTENTS}

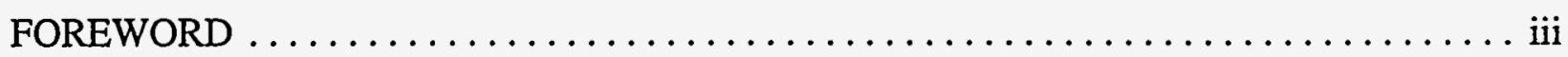

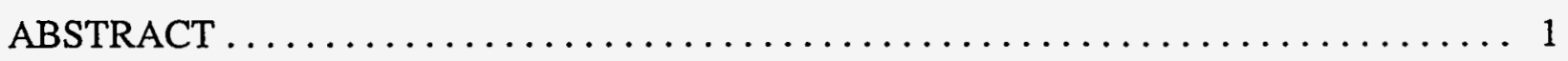

1 INTRODUCTION $\ldots \ldots \ldots \ldots \ldots \ldots \ldots \ldots \ldots \ldots \ldots \ldots \ldots \ldots \ldots \ldots \ldots \ldots \ldots \ldots$

2 DESCRIPTION OF POWER MARKETING ALTERNATIVES AND DAM OPERATIONAL SCENARIOS $\ldots \ldots \ldots \ldots \ldots \ldots \ldots \ldots \ldots \ldots \ldots \ldots \ldots$

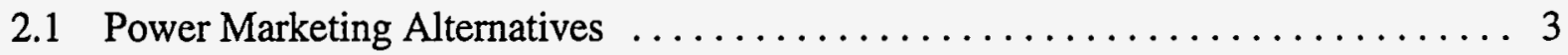

2.2 Glen Canyon Dam Operational Scenarios $\ldots \ldots \ldots \ldots \ldots \ldots \ldots \ldots \ldots \ldots \ldots \ldots \ldots$

2.3 Flaming Gorge Dam Operational Scenarios . . . . . . . . . . . . . . . . . . 6

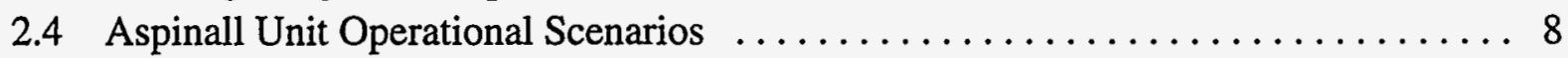

2.4.1 Year-Round High Fluctuating Flow $\ldots \ldots \ldots \ldots \ldots \ldots \ldots \ldots \ldots . \ldots$

2.4.2 Year-Round High Fluctuating Flow, with Steady Flow at Crystal Dam ..... 9

2.4 .3 Year-Round Moderate Fluctuating Flow $\ldots \ldots \ldots \ldots \ldots \ldots \ldots \ldots$

2.4 .4 Year-Round Steady Flow $\ldots \ldots \ldots \ldots \ldots \ldots \ldots \ldots \ldots \ldots \ldots$

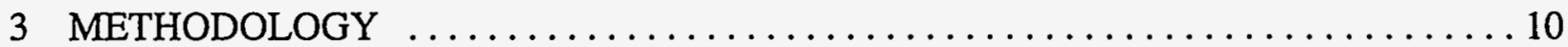

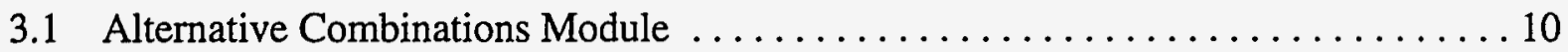

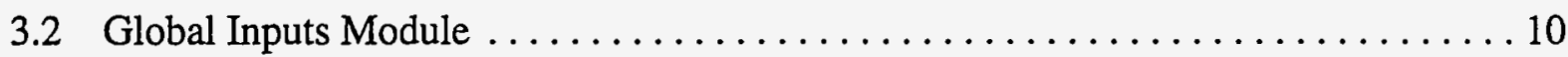

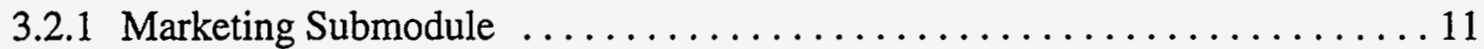

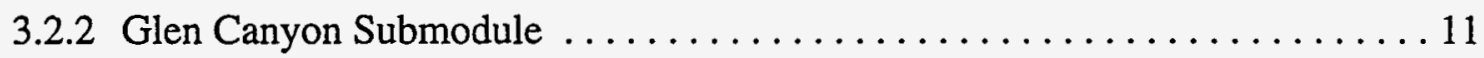

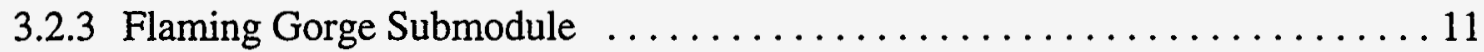

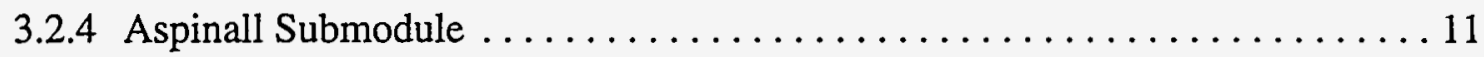

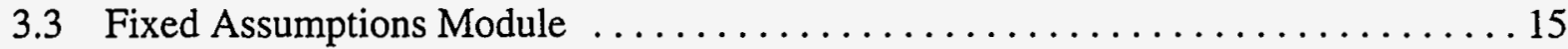

3.4 Main Module ........................................ 15

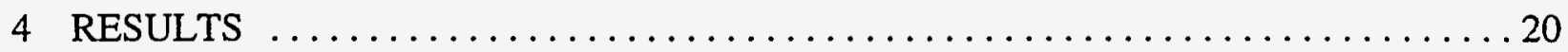

5 SELECTION OF POWER MARKETING ALTERNATIVES AND DAM

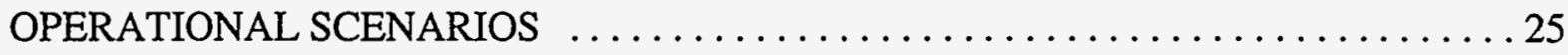

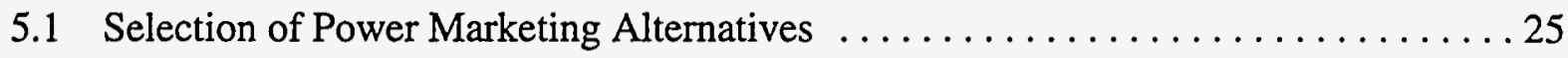

5.2 Selection of Operational Scenario Combinations .................... 25

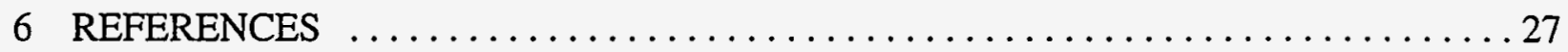




\section{CONTENTS (Cont.)}

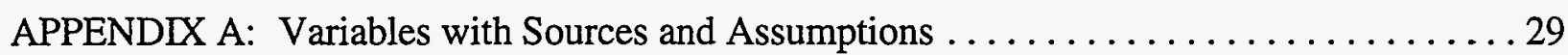

APPENDIX B: SPASM Estimates of Wholesale Power Costs of Marketing Alternative/Operational Scenario Combinations $\ldots \ldots \ldots \ldots \ldots \ldots . \ldots . \ldots 1$

\section{TABLES}

1 Characteristics of the Power Marketing Alternatives $\ldots \ldots \ldots \ldots \ldots \ldots \ldots \ldots \ldots$

2 Characteristics of Operational Scenarios for Glen Canyon Dam $\ldots \ldots \ldots \ldots \ldots \ldots$

3 Characteristics of Operational Scenarios for Flaming Gorge Dam $\ldots \ldots \ldots \ldots \ldots$. 7

4 Operational Scenarios for the Aspinall Unit to Support the Power Marketing Alternatives $\ldots \ldots \ldots \ldots \ldots \ldots \ldots \ldots \ldots \ldots \ldots \ldots \ldots, 8$

5 Exogenous Inputs for the Power Marketing Alternatives $\ldots \ldots \ldots \ldots \ldots \ldots \ldots \ldots$

6 Exogenous Inputs for Glen Canyon Operational Scenarios $1-7 \ldots \ldots \ldots \ldots \ldots \ldots \ldots$

7 Exogenous Inputs for Flaming Gorge Operational Scenarios $1-4 \ldots \ldots \ldots \ldots \ldots \ldots$

8 Exogenous Inputs for Aspinall Operational Scenarios $1-4 \ldots \ldots \ldots \ldots \ldots \ldots \ldots$

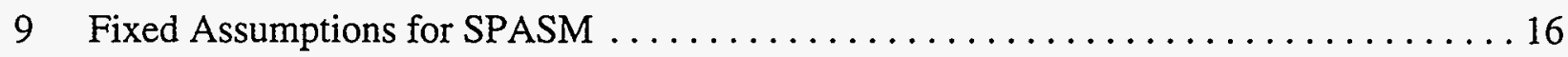

10 Summary Statistics for the Power Marketing Alternatives $\ldots \ldots \ldots \ldots \ldots \ldots \ldots$

11 Power Marketing Alternatives Selected for Further Study $\ldots \ldots \ldots \ldots \ldots \ldots \ldots \ldots$

12 Operational Scenario Combinations Selected on the Basis

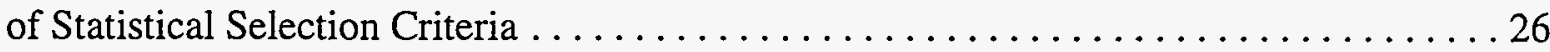

13 Final Operational Scenario Combinations Selected for the EIS $\ldots \ldots \ldots \ldots \ldots 26$

B.1 SPASM Estimates of Wholesale Power Costs $\ldots \ldots \ldots \ldots \ldots \ldots \ldots \ldots \ldots \ldots \ldots \ldots$ 


\section{FIGURES}

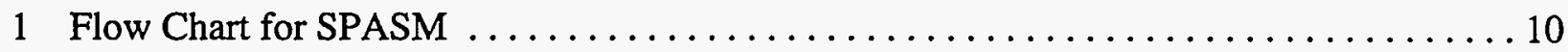

2 Frequency Distribution of Wholesale Power Costs for the No Action Alternative . . . . . 21

3 Frequency Distribution of Wholesale Power Costs for Marketing Alternative $1 \ldots \ldots \ldots 21$

4 Frequency Distribution of Wholesale Power Costs for Marketing Alternative $2 \ldots \ldots 22$

5 Frequency Distribution of Wholesale Power Costs for Marketing Alternative $3 \ldots \ldots 22$

6 Frequency Distribution of Wholesale Power Costs for Marketing Alternative $4 \ldots \ldots 23$

7 Frequency Distribution of Wholesale Power Costs for Marketing Alternative $5 \ldots \ldots \ldots 23$

8 Frequency Distribution of Wholesale Power Costs for Marketing Alternative $6 \ldots \ldots 24$

9 Frequency Distribution of Wholesale Power Costs for All Marketing Alternatives . . . . . 24 


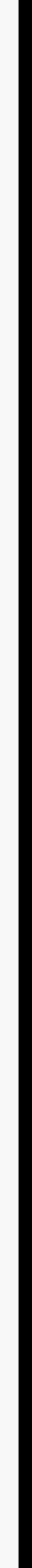




\title{
SLCA/IP POWER ALTERNATIVE SCREENING METHOD (SPASM)
}

by

\author{
S.C. Palmer and J.D. Ancrile
}

\begin{abstract}
This report describes the SLCA/IP Power Alternative Screening Method (SPASM), which was used to screen 784 possible combinations of electric power marketing alternatives and dam operational scenarios to provide a representative range for analysis in the Western Area Power Administration Salt Lake City Area Integrated Projects (SLCA/IP) Electric Power Marketing Environmental Impact Statement (EIS). Each combination consists of one energy and capacity commitment level and one operational scenario for each of the hydroelectric facilities at Glen Canyon Dam, Flaming Gorge Dam, and the Aspinall Unit. The total annual cost to the SLCA/IP firm power customers of each of the 784 combinations is estimated and included in a relative frequency distribution. A relative frequency distribution is also generated for each marketing alternative. The number of combinations is reduced to 12 by taking the mean value and endpoint value for each of four marketing alternatives. Some minor deviations from this procedure, which are made for political purposes, are explained.
\end{abstract}

\section{INTRODUCTION}

The Western Area Power Administration (Western) Salt Lake City Area Integrated Projects (SLCA/IP) Electric Power Marketing Environmental Impact Statement (EIS) evaluates seven power marketing alternatives. These power marketing alternatives consist of various combinations of low, medium, and high capacity levels and energy levels and a number of operational scenarios at three hydroelectric facilities under Western's influence. Glen Canyon Dam has seven different combinations of capacity, on-peak energy, and off-peak energy, including a No Action Alternative. Flaming Gorge Dam has four different combinations of capacity, on-peak energy, and off-peak energy, including a No Action Alternative. The Aspinall Unit has four different combinations of capacity, on-peak energy, and off-peak energy, including a No Action Alternative. These combine to a total of 784 possible variations, calculated by multiplying the number of power marketing alternatives (7) by the number of operational scenarios at Glen Canyon (7) by the number at Flaming 
Gorge (4) by the number at Aspinall (4). To perform the economic analysis of Western's impact on the region of influence, the total number of marketing-alternative/operational-scenario combinations was reduced to a few that were appropriately representative by using the SLCA/IP Power Alternative Screening Method (SPASM). Since that time, operational scenarios at Glen Canyon Dam, Flaming Gorge Dam, and the Aspinall Unit have changed. The most significant change was at Aspinall, which now has two (not four) operational scenarios. 


\section{DESCRIPTION OF POWER MARKETING ALTERNATIVES AND DAM OPERATIONAL SCENARIOS}

\subsection{POWER MARKETING ALTERNATIVES}

The seven marketing alternatives being analyzed for the Western EIS are differentiated by the level of power commitment, level of energy commitment, and load factor percentage. The No Action Alternative (NA) is based on the 1978 marketing program of a low capacity and high energy commitment. A $50 \%$ load factor is associated with this alternative. Alternative 1 was originally the proposed-action alternative; it consists of high power and high energy commitment levels. Alternative 2 is the high peaking alternative, with a high power commitment but a low energy commitment, and is associated with a peaking-type operational option. Alternative 3 is defined as having lower power and energy commitment levels and is thus a lower supply risk. Alternative 4 has the lowest supply risk commitment levels and a relatively high load factor. Alternative 5 provides the energy equivalent of generation at a steady mode of power plant operation and is associated with a baseload type of operational option. Alternative 6 is a moderate level of supply risk alternative. Table 1 shows the power and energy commitment levels and the load factors for each marketing alternative that were used to develop the global parameters.

\subsection{GLEN CANYON DAM OPERATIONAL SCENARIOS}

Glen Canyon has two types of operational scenarios: fluctuating flow and steady flow (Table 2). The steady-flow scenarios have been developed to substantially reduce fluctuations

TABLE 1 Characteristics of the Power Marketing Alternatives

\begin{tabular}{cccc}
\hline $\begin{array}{c}\text { Power } \\
\text { Marketing } \\
\text { Alternative }\end{array}$ & $\begin{array}{c}\text { Power } \\
\text { Commitment } \\
(\mathrm{MW})\end{array}$ & $\begin{array}{c}\text { Energy } \\
\text { Commitment } \\
(\mathrm{GWh})\end{array}$ & $\begin{array}{c}\text { Load } \\
\text { Factor } \\
(\%)\end{array}$ \\
\hline NA & 1,291 & 5,700 & 50 \\
1 & 1,449 & 6,156 & 48.5 \\
2 & 1,450 & 3,300 & 26 \\
3 & 1,225 & 4,000 & 37 \\
4 & 550 & 3,300 & 68 \\
5 & 625 & 5,475 & 100 \\
6 & 1,000 & 4,750 & 54 \\
\hline
\end{tabular}


TABLE 2 Characteristics of Operational Scenarios for Glen Canyon Dam

\begin{tabular}{|c|c|c|c|c|c|c|c|}
\hline \multirow[b]{3}{*}{ Parameter } & \multirow{3}{*}{$\begin{array}{c}\text { Continuation } \\
\text { of Historic Flows: } \\
\text { Scenario 1, No Action }\end{array}$} & \multirow{2}{*}{\multicolumn{3}{|c|}{ Restricted Fluctuating Flows }} & \multicolumn{3}{|c|}{ Stcady Flows } \\
\hline & & & & & \multirow{2}{*}{$\begin{array}{l}\text { Existing Monthly } \\
\text { Volume: } \\
\text { Scenario } 5 \\
\end{array}$} & \multirow{2}{*}{$\begin{array}{l}\text { Seasonally } \\
\text { Adjusted: } \\
\text { Scenario6 }\end{array}$} & \multirow[b]{2}{*}{$\begin{array}{l}\text { Year-Round: } \\
\text { Scenario } 7\end{array}$} \\
\hline & & $\begin{array}{l}\text { High: } \\
\text { Scenario } 2\end{array}$ & $\begin{array}{l}\text { Moderate: } \\
\text { Scenario } 3\end{array}$ & $\begin{array}{c}\text { Interim Low: } \\
\text { Scenario } 4\end{array}$ & & & \\
\hline $\begin{array}{l}\text { Minimum } \\
\text { release }^{\text {a }}(\mathrm{cfs})\end{array}$ & $\begin{array}{l}\text { 1,000 Labor Day-Easter } \\
\text { 3,000 Easter-Labor Day }\end{array}$ & $\begin{array}{l}3,000,5,000 \text {, or } 8,000 \text {, } \\
\text { depending on monthly } \\
\text { volume, firm load, and } \\
\text { market conditions }\end{array}$ & 5,000 & $\begin{array}{l}8,000 \text { between } \\
7 \text { a.m. and } 7 \text { p.m; } \\
5,000 \text { at night }\end{array}$ & 8,000 & $\begin{array}{l}\text { 8,000 Oct.-Nov. } \\
\text { 8,500 Dec. } \\
\text { 11,000 Jan.-March } \\
\text { 12,500 April } \\
\text { 18,000 May-June } \\
\text { 12,500 July } \\
\text { 9,000 Aug.-Sept. }\end{array}$ & $\begin{array}{l}\text { Yearly volume } \\
\text { prorated d }^{d}\end{array}$ \\
\hline $\begin{array}{l}\text { Maximum } \\
\text { release (cfs) }\end{array}$ & 31,500 & 31,500 & $31,500^{\mathrm{e}}$ & 20,000 & $\begin{array}{l}\text { Monthly volumes } \\
\text { prorated }\end{array}$ & 18,000 & $\begin{array}{l}\text { Yearly volume } \\
\text { prorated }^{\mathrm{d}}\end{array}$ \\
\hline $\begin{array}{l}\text { Allowable daily } \\
\text { change in flow } \\
\text { (cfs/d) }\end{array}$ & $\begin{array}{l}\text { 30,500 Labor Day-Easter } \\
\text { 28,500 Easter-Labor Day }\end{array}$ & $15,000-22,000$ & $\begin{array}{l} \pm 45 \% \text { of mean } \\
\text { flow for the } \\
\text { month, not to } \\
\text { exceed } \pm 6,000\end{array}$ & $\begin{array}{c}5,000 \\
6,000, \text { or } 8,000^{f}\end{array}$ & $\pm 1,000^{\mathrm{g}}$ & $\pm 1,000^{8}$ & $\pm 1,000^{8}$ \\
\hline $\begin{array}{l}\text { Allowable } \\
\text { scheduled } \\
\text { ramping (cfs/h) }\end{array}$ & Unrestricted & $\begin{array}{l}\text { Unrestricted up to } \\
5,000 \text { or } 4,000 \text { down }\end{array}$ & $\begin{array}{c}\text { 4,000 up } \\
2,500 \text { down }\end{array}$ & $\begin{array}{l}2,500 \text { up } \\
1,500 \text { down }\end{array}$ & $\begin{array}{l}2,000 \mathrm{cfs} / \mathrm{d} \\
\text { between months }\end{array}$ & $\begin{array}{l}2,000 \mathrm{cfs} / \mathrm{d} \\
\text { between months }\end{array}$ & $\begin{array}{l}2,000 \mathrm{cfs} / \mathrm{d} \\
\text { between months }\end{array}$ \\
\hline
\end{tabular}

a In high-volume release months, the allowable daily change would require higher minimum flows.

b Releases each weckday during recreation season (Easter to Labor Day) would average not less than $8,000 \mathrm{cfs}$ for the period from 8 a.m. to midnight.

c Based on an 8.23-million-acre-ft year; in years with higher releases, additional water would be added equally to each month, subject to an 18,000 -cfs maximum.

d For an 8.23-million-acre-ft year, steady flow would be about $11,400 \mathrm{cfs}$.

e May be exceeded during habitat-maintenance flows.

f Daily fluctuation limit of $5,000 \mathrm{cfs}$ for monthly release volumes less than 600,000 acre-ft; $6,000 \mathrm{cfs}$ for monthly release volumes of $600,000-800,000$ acre-ft; and $8,000 \mathrm{cfs}$ for monthly volumes over 800,000 acre-ft.

$g$ Adjustments would allow for small power system load changes.

Source: Adapted from Reclamation (1993), p. 18. 
resulting from peaking power generation and to protect downstream resources. Releases may be adjusted throughout the year to avoid spills and to balance storage between Lake Powell and Lake Mead. The Year-Round Steady-Flow Scenario was developed to release water from Glen Canyon Dam at a steady year-round rate, eliminating daily and monthly river fluctuations except as necessary for monthly forecasted adjustments. The Seasonally Adjusted Steady-Flow Scenario features a flow regime that addresses the varying seasonal needs of downstream biological resources and includes water releases at a constant rate within each month. Although the cooperating agencies approve of the concept of this alternative, specific operational parameters are still being reviewed. The ExistingMonthly-Volume Steady-Flow Scenario integrates the concept of monthly steady flows based on current water delivery schedules. Water would be released from the dam at a constant rate during any given month.

All of the fluctuating-flow scenarios would allow for some use of peaking power. The scheduling of annual and monthly release volumes would be determined by using existing practices. Releases may be adjusted throughout the year to avoid spills and to balance storage between Lake Powell and Lake Mead. Under the Low-Fluctuating-Flow Scenario, fluctuations would be limited to a change of 5,000,6,000, or 8,000 cubic feet per second (cfs) (or approximately a 3-ft river stage fluctuation in the Grand Canyon) over a 24-hour period. The total change per day (d) would be a function of monthly release volumes. Maximum flows would be limited to 20,000 cfs. Minimum flows would be $8,000 \mathrm{cfs}$ between 7 a.m. and 7 p.m. and would be 5,000 cfs at night. Ramping rates would be limited to 2,500 cfs/per hour (h) for increasing flows and to $1,500 \mathrm{cfs} / \mathrm{h}$ for decreasing flows. This scenario closely approximates the current interim operating criteria.

Under the Moderate-Fluctuating-Flow Scenario the daily change in flow in a 24-hour period would be limited to $12,000 \mathrm{cfs}$ when the monthly release volume is 800,000 acre-ft or greater. The change is limited to $\pm 45 \%$ of the mean monthly flow for volumes less than 800,000 acre-ft. This limit amounts to 7,500 cfs for a 500,000-acre-ft monthly volume. Maximum flows would be limited to $31,500 \mathrm{cfs}$; any releases greater than $31,500 \mathrm{cfs}$ would be steady flow. Minimum flows would be limited to $5,000 \mathrm{cfs}$.

The High-Fluctuating-Flow Scenario relates releases to hydrology, power system flexibility, and specific resource needs. Fluctuations would range from 15,000 to $22,000 \mathrm{cfs}$ over a 24-hour period, depending on the monthly release volume. The maximum flow would be limited to $31,500 \mathrm{cfs}$; any releases greater than 31,500 cfs would be steady flow. Minimum flows would be $3,000,5,000$, or $8,000 \mathrm{cfs}$, depending on monthly volume, firm power load, and market conditions. Releases would be steady during months when the release volume exceeds 1 million acre-ft.

Scenario 1, the No Action Alternative, reflects historic operations and forms the basis for comparing impacts. The maximum daily flow is determined by a combination of water availability and power demands in any month. Peak discharges under existing normal operations would not exceed $31,500 \mathrm{cfs}$. Use of the full power plant capacity $(33,200 \mathrm{cfs})$ would be studied as a additional 
scenario. Historically, minimum flows allowable have been 1,000 cfs from Labor Day until Easter and 3,000 cfs from Easter until Labor Day, the recreation season.

\subsection{FLAMUNG GORGE DAM OPERATIONAL SCENARIOS}

Four operational scenarios for Flaming Gorge Dam were developed for Western's EIS. As described subsequently, three of these scenarios comply with the Biological Opinion issued by the U.S. Fish and Wildlife Service (1992). Compliance with the opinion is described as follows:

- A target flow at Jensen, Utah, is set between 1,100 and $1,800 \mathrm{cfs}$ for summer and autumn, except that up to 2,400 cfs would be allowed after September 15 for wet years. The periods covered are July 20-October 31 for a wet year, July 10-October 31 for a moderate year, and June 20-October 21 for a dry year.

- Variations of flow at Jensen are limited to a total of $25 \%$ around the target flow for any 24-hour period. Variations above or below the target should be as close as possible.

- Except due to the effects of storm runoff, the flow at Jensen should stay within the range of 1,100 to $1,800 \mathrm{cfs}$, or up to $2,400 \mathrm{cfs}$ after September 15 for wet years.

Release patterns were developed for representative wet, moderate, and dry years (1983, 1987, and 1989, respectively). Release patterns for the four hydropower operational scenarios are presented in Table 3. The principal difference in the hydropower operational scenarios is the hourly fluctuation characteristics of the release rate, as follows:

- Scenario 1 - Year-Round High Fluctuating Flow: The ramping rate, maximum fluctuation, and maximum and minimum releases used to derive the representative release patterns are detailed in Table 3 . The minimum release is $800 \mathrm{cfs}$; the maximum release is assumed to be $4,700 \mathrm{cfs}$, with no limit on maximum daily fluctuations. ${ }^{1}$ Ramping rate restrictions are $3,900 \mathrm{cfs} / \mathrm{h}$ (minimum flow to maximum generator capacity). This operational scenario

1 The maximum possible release rate for Flaming Gorge Dam with uprated conditions could be in excess of 4,950 cfs for full reservoir conditions; however, such reservoir conditions would occur only for limited periods. 
TABLE 3 Characteristics of Operational Scenarios for Flaming Gorge Dam

\begin{tabular}{|c|c|c|c|c|}
\hline \multirow[b]{2}{*}{ Parameter } & \multirow{2}{*}{$\begin{array}{c}\text { Year-Round } \\
\text { High } \\
\text { Fluctuating Flow: } \\
\text { Scenario } 1 \\
\end{array}$} & \multicolumn{3}{|c|}{ Seasonally Adjusted Flows } \\
\hline & & $\begin{array}{c}\text { High } \\
\text { Fluctuating: } \\
\text { Scenario } 2\end{array}$ & $\begin{array}{l}\text { Moderate } \\
\text { Fluctuating: } \\
\text { Scenario } 3\end{array}$ & $\begin{array}{l}\text { Steady: } \\
\text { Scenario } 4\end{array}$ \\
\hline Minimum release (cfs) & 800 & 800 & 800 & 800 \\
\hline Maximum release (cfs) & 4,700 & 4,700 & 4,700 & $\begin{array}{l}\text { Same as } \\
\text { minimum } \\
\text { releases }\end{array}$ \\
\hline $\begin{array}{l}\text { Allowable daily change } \\
\text { in flow (cfs/d) }\end{array}$ & 3,900 & 3,900 & 1,950 & 0 \\
\hline $\begin{array}{l}\text { Allowable scheduled } \\
\text { ramping }(\mathrm{cfs} / \mathrm{h})\end{array}$ & 3,900 & 3,900 & 1,950 & 0 \\
\hline
\end{tabular}

would not comply with the Biological Opinion. The scenario is representative of maximum power plant operations and is considered here for comparative purposes. Consideration of this operational scenario enabled a determination of the environmental consequences of the seasonal and daily adjustment of releases required by the opinion.

- Scenario 2 - Seasonally Adjusted High Fluctuating Flow. Hourly releases would reach the maximum fluctuation feasible as limited by the Biological Opinion, water available for release, minimum release requirement, and power plant capacity. Volumes would be adjusted seasonally to meet the requirements of the Biological Opinion.

- Scenario 3 - Seasonally Adjusted Moderate Fluctuating Flow. Hourly releases would have fluctuations limited to $50 \%$ of the flow change identified under Scenario 2. Volumes would be adjusted seasonally to meet the requirements of the Biological Opinion.

- Scenario 4 - Seasonally Adjusted Steady Flow. Hourly releases would be constant during the day. Volumes would be adjusted seasonally to meet the requirements of the Biological Opinion. 


\subsection{ASPINALL UNIT OPERATIONAL SCENARIOS}

Operational scenarios for the Aspinall Unit were developed for use in SPASM before they were finally determined for use in Western's EIS. The four operational scenarios for Aspinall developed for use in SPASM are summarized here in Table 4.

\subsubsection{Year-Round High Fluctuating Flow}

This operational scenario represents the capacity and energy levels used for operation of the Aspinall Unit prior to May 8, 1992, when the Bureau of Reclamation announced that it would

TABLE 4 Operational Scenarios for the Aspinall Unit to Support the Power Marketing Alternatives

\begin{tabular}{|c|c|c|c|c|c|}
\hline $\begin{array}{l}\text { Operational } \\
\text { Scenario } \\
\text { and Unit }\end{array}$ & $\begin{array}{c}\text { Minimum } \\
\text { Release } \\
\text { (cfs) }\end{array}$ & $\begin{array}{c}\text { Maximum } \\
\text { Release } \\
\text { (cfs) }\end{array}$ & $\begin{array}{l}\text { Maximum } \\
\text { Daily } \\
\text { Fluctuation } \\
\text { (cfs/d) }\end{array}$ & $\begin{array}{c}\text { Ramping } \\
\text { Up } \\
\text { (cfs/h) }\end{array}$ & $\begin{array}{c}\text { Ramping } \\
\text { Down } \\
\text { (cfs/h) }\end{array}$ \\
\hline \multicolumn{6}{|c|}{ No Action: Scenario 1} \\
\hline Crystal & 300 & 1,600 & 1,300 & 1,300 & 1,300 \\
\hline Morrow Point & 0 & 5,300 & 5,300 & 5,300 & 5,300 \\
\hline Blue Mesa & 0 & 3,700 & 3,700 & 3,700 & 3,700 \\
\hline \multicolumn{6}{|c|}{ Year-Round High Fluctuating Flow, with Steady Flow at Crystal Dam: Scenario 2} \\
\hline Crystal & a & a & a & None & None \\
\hline Morrow Point & 0 & 5,300 & 5,300 & 5,300 & 5,300 \\
\hline Blue Mesa & 0 & 3,700 & 3,700 & 3,700 & 3,700 \\
\hline \multicolumn{6}{|c|}{ Year-Round Moderate Fluctuating Flow: Scenario 3} \\
\hline Crystal & a & a & a & None & None \\
\hline Morrow Point & 0 & 5,300 & 3,975 & 9,200 & 4,200 \\
\hline Blue Mesa & 0 & 3,700 & 2,775 & 2,900 & 2,900 \\
\hline \multicolumn{6}{|c|}{ Year-Round Steady Flow: Scenario 4} \\
\hline Crystal & a & a & a & None & None \\
\hline Morrow Point & a & a & $\mathrm{a}$ & None & None \\
\hline Blue Mesa & a & a & a & None & None \\
\hline
\end{tabular}

a Steady flow: no fluctuations. 
operate the Aspinall Unit according to a draft contract intended to provide water to the Black Canyon of the Gunnison National Monument. The project-dependent capacity is the post-1989 marketable capacity for the Aspinall Unit. On-peak energy was calculated by multiplying the average annual energy of $849 \mathrm{GWh}$ by 0.789 . This number is the ratio of on-peak energy to total energy for the Glen Canyon No Action Alternative.

\subsubsection{Year-Round High Fluctuating Flow, with Steady Flow at Crystal Dam}

This operational scenario was developed to provide steady flows at Crystal Dam. This dam is the farthest downstream of the three Aspinall Unit dams and was constructed to be a reregulation facility. Crystal Dam operates in a near-steady regime. Changing the operation to provide steady flow at Crystal Dam does not alter the project-dependent capacity or the on-peak energy.

\subsubsection{Year-Round Moderate Fluctuating Flow}

This operational scenario reduces the fluctuations at the Blue Mesa and Morrow Point power plants by $25 \%$ compared with the Year-Round High-Fluctuating-Flow Scenario. Crystal Dam operates under a steady-flow regime. Project-dependent capacity is reduced to $328 \mathrm{MW}$, and on-peak energy is reduced to $590 \mathrm{GWh}$.

\subsubsection{Year-Round Steady Flow}

Under this operational scenario, all of the Aspinall Unit dams release water in a steady flow throughout the day. The Blue Mesa and Morrow Point power plants are not operated as peaking facilities. Project-dependent capacity is reduced to $235 \mathrm{MW}$, and on-peak energy is reduced to $56 \mathrm{GWh}$. 


\section{METHODOLOGY}

This section describes the methodology used to screen the number of alternative combinations. Figure 1 illustrates the modules that make up SPASM.

\subsection{ALTERNATIVE COMBINATIONS MODULE}

This module assigns the proper amount of capacity, on-peak energy, and off-peak energy from the Global Inputs Module corresponding to each alternative combination.

\subsection{GLOBAL INPUTS MODULE}

The Global Inputs Module contains the amount of capacity, on-peak energy, and off-peak energy corresponding to each alternative combination. This module is organized into the Marketing, Glen Canyon, Flaming Gorge, and Aspinall submodules.

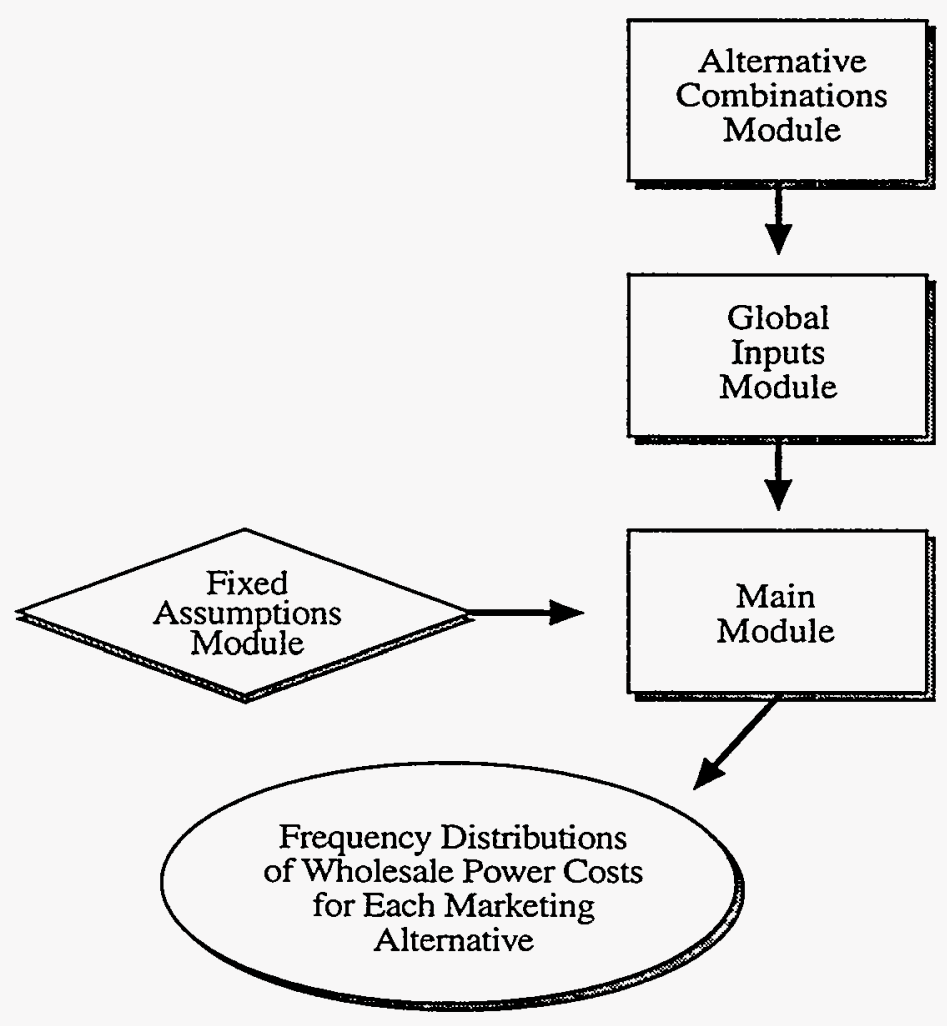

FIGURE 1 Flow Chart for SPASM 


\subsubsection{Marketing Submodule}

Table 5 illustrates the exogenous inputs for the seven marketing alternatives that have been developed for evaluation. These inputs are derived from the commitment levels from Table 1.

\subsubsection{Glen Canyon Submodule}

Table 6 describes the exogenous inputs for each of the Glen Canyon operational scenarios.

\subsubsection{Flaming Gorge Submodule}

Table 7 describes the exogenous inputs for each of the Flaming Gorge operational scenarios.

\subsubsection{Aspinall Submodule}

A total annual energy value of $1,059 \mathrm{GWh}$ was separated into an on-peak value of $605 \mathrm{GWh}$ and an off-peak value of $454 \mathrm{GWh}$ (separated similarly to Glen Canyon) and was used as

TABLE 5 Exogenous Inputs for the Power Marketing Alternatives

\begin{tabular}{ccccc}
\hline $\begin{array}{c}\text { Marketing } \\
\text { Alternative }\end{array}$ & $\begin{array}{c}\text { Capacity } \\
\text { (MW) }\end{array}$ & $\begin{array}{c}\text { Annual On-Peak } \\
\text { Energy } \\
(\text { GWh }\end{array}$ & $\begin{array}{c}\text { Annual Off-Peak } \\
\text { Energy } \\
\text { (GWh) }\end{array}$ & $\begin{array}{c}\text { Minimum Scheduled } \\
\text { Requirement (MSR) } \\
(\%)\end{array}$ \\
\hline NA & 1,291 & 4,005 & 1,695 & 35 \\
1 & 1,449 & 4,253 & 1,903 & 35 \\
2 & 1,450 & 1,396 & 1,904 & 10 \\
3 & 1,225 & 2,391 & 1,609 & 15 \\
4 & 550 & 2,578 & 722 & 52 \\
5 & 625 & 4,654 & 821 & 100 \\
6 & 1,000 & 3,437 & 1,313 & 33 \\
\hline
\end{tabular}

a Energy commitment minus off-peak energy.

b Presumes that customers use the minimum scheduled delivery requirement (MSR) as the minimum amount of off-peak energy they will schedule from Western. Annual offpeak energy is calculated by multiplying the capacity commitment for each alternative by the MSR multiplied by 3,752 (number of off-peak hours in a year). 
TABLE 6 Exogenous Inputs for Glen Canyon Operational Scenarios 1-7

\begin{tabular}{lccc}
\hline \multicolumn{1}{c}{$\begin{array}{c}\text { Project- } \\
\text { Operational } \\
\text { Scenario }\end{array}$} & $\begin{array}{c}\text { Dependent } \\
\text { Capacity }^{\mathrm{a}} \\
\text { (MW) }\end{array}$ & $\begin{array}{c}\text { On-Peak } \\
\text { Energy } \\
\text { (GWh) }\end{array}$ & $\begin{array}{c}\text { Off-Peak } \\
\text { Energy } \\
\text { (GWh) }\end{array}$ \\
\hline 1: No Action & 999 & $3,610^{\mathrm{b}}$ & $963^{\mathrm{b}}$ \\
2: High Fluctuating & 975 & $3,502^{\mathrm{c}}$ & $1,071^{\mathrm{d}}$ \\
3: Moderate Fluctuating & 620 & $3,393^{\mathrm{e}}$ & $1,180^{\mathrm{d}}$ \\
4: Low Fluctuating & 594 & $3,277^{\mathrm{f}}$ & $1,296^{\mathrm{d}}$ \\
5: Existing Steady & 413 & $2,457^{\mathrm{g}}$ & 1,840 \\
6: Adjusted Steady & 227 & $2,457^{\mathrm{g}}$ & 1,840 \\
7: Year-Round Steady & 310 & $2,457^{\mathrm{g}}$ & 1,840 \\
\hline
\end{tabular}

a Average of winter and summer capacity multiplied by 0.734 (ratio of Glen Canyon nameplate capacity to nameplate capacity of all units $=1,300 / 1,771$ ).

b Based on 1996 projection (a close-to-average year) by Western. The total 1996 projected energy is 4,573 GWh.

c Scenario 1 (No Action) on-peak energy multiplied by 0.97 .

d Total projected 1996 energy at Glen Canyon $(4,573)$ minus onpeak energy.

e Scenario 1 (No Action) on-peak energy multiplied by 0.94 .

$f$ Scenario 1 (No Action) on-peak energy multiplied by 0.91 .

g For the steady-flow scenarios, the total annual energy value of $4,297 \mathrm{GWh}$ was separated into an on-peak value of 2,457 by multiplying the total value by the ratio of annual on-peak hours to the number of hours in a year $(0.5717)$. The off-peak value of $1,840 \mathrm{GWh}$ is the total value multiplied by the ratio of annual off-peak hours to the total number of hours in a year (0.4283) and was used as an exogenous input for Glen Canyon into SPASM. The total value is the median from the historic frequency distribution 1979-1988 multiplied by an adjustment factor of 1.077 for the high number of wet hydrologies during this period. 
TABLE 7 Exogenous Inputs for Flaming Gorge Operational Scenarios 1-4

\begin{tabular}{cccc}
\hline Operational & $\begin{array}{c}\text { Project- } \\
\text { Dependent } \\
\text { Capacity } \\
\text { Scenario }\end{array}$ & $\begin{array}{c}\text { On-Peak } \\
\text { Energy } \\
(\mathrm{MWh})\end{array}$ & $\begin{array}{c}\text { Off-Peak } \\
\text { Energy }^{\mathrm{a}} \\
(\mathrm{GWh})\end{array}$ \\
\hline & & & \\
1 & $115^{\mathrm{b}}$ & $464^{\mathrm{c}}$ & 124 \\
2 & 115 & $441^{\mathrm{d}}$ & 147 \\
3 & $69^{\mathrm{e}}$ & $419^{\mathrm{f}}$ & 169 \\
4 & $60^{\mathrm{g}}$ & $392^{\mathrm{h}}$ & 196 \\
\hline
\end{tabular}

a Total average annual energy generated at Flaming Gorge (588) minus estimated on-peak energy.

b Uprated capacity at Flaming Gorge (150 MW) multiplied by 0.7685 (Glen Canyon capacity; No Action, summer and winter average divided by 1,771 , the nameplate capacity of all units); i.e., the ratio of the total nameplate of all units to the marketable capacity as determined by the Glen Canyon Dam EIS.

c Total average annual energy (588) multiplied by 0.789 (the ratio of on-peak energy to total energy in the Glen Canyon No Action Scenario).

d No Action on-peak energy multiplied by 0.95 .

e Uprated capacity at Flaming Gorge (150 MW) multiplied by 0.46 .

f Flaming Gorge Operational Scenario 2 on-peak energy multiplied by 0.95 .

g Uprated capacity at Flaming Gorge (150 MW) multiplied by 0.40 .

h Total average annual energy (588) multiplied by 0.6667 (the ratio of on-peak hours to total hours). 
TABLE 8 Exogenous Inputs for Aspinall

\section{Operational Scenarios 1-4}

\begin{tabular}{cccc}
\hline $\begin{array}{c}\text { Project- } \\
\text { Operational } \\
\text { Scenario }\end{array}$ & $\begin{array}{c}\text { Capacity } \\
\text { (MW) }\end{array}$ & $\begin{array}{c}\text { On-Peak } \\
\text { Energy } \\
\text { (GWh) }\end{array}$ & $\begin{array}{c}\text { Off-Peak } \\
\text { Energy } \\
\text { (GWh) }\end{array}$ \\
\hline 1 & $335^{\mathrm{a}}$ & $670^{\mathrm{b}}$ & 179 \\
2 & 335 & 670 & 179 \\
3 & $328^{\mathrm{c}}$ & $590^{\mathrm{d}}$ & 259 \\
4 & $235^{\mathrm{e}}$ & $447^{\mathrm{f}}$ & 283 \\
\hline
\end{tabular}

a Total No Action marketable capacity.

b Total average annual energy generated at the Aspinall Unit.

c Total No Action marketable capacity (335 MW) multiplied by 0.98 .

d No Action on-peak energy (670 GWh) multiplied by 0.88 .

e Total No Action marketable capacity (335 MW) multiplied by 0.70 .

f No Action on-peak energy (670 GWh) multiplied by 0.6667 .

an exogenous input for Aspinall to go into SPASM. Table 8 illustrates the characteristics of the four Aspinall operational scenarios that were used as exogenous inputs for the Aspinall submodule. The project-dependent capacity at Aspinall for each alternative is given by

$$
P D C^{\#}=\sum_{f} \overline{c f s_{f}^{\#}} C F_{c f s-M W}^{f}
$$

where

$$
\begin{aligned}
P D C^{\#}= & \text { project-dependent capacity associated with each alternative, } \\
f= & \text { index of Aspinall facilities (Blue Mesa, Crystal, and Morrow Point), } \\
\overline{c f s} s_{f}^{\#}= & \text { average flow in cubic feet per second for each alternative from the } \\
& \begin{array}{l}
\text { Aspinall hydrographs developed to simulate flow conditions under the } \\
\text { various operational scenarios, and }
\end{array}
\end{aligned}
$$


$\begin{aligned} C F_{c s-M W}^{f}= & \text { conversion factor for transforming flow in cubic feet per second to } \\ & \text { capacity in megawatts. }\end{aligned}$

Appendix A contains a list of the variables considered in this report.

\subsection{FIXED ASSUMPTIONS MODULE}

Table 9 contains input data used by SPASM that do not vary from one iteration of SPASM to another. These data are called fixed assumptions.

\subsection{MAIN MODULE}

The amount of long-term wholesale power costs is computed by

$$
\begin{aligned}
L W P= & \left(C_{S L}^{1} \times r_{S L}^{1}\right)+\left(C_{S L}^{2,3} \times r_{S L}^{2,3}\right)+\left(P_{X S}^{1} \times r_{X S}^{1}\right) \\
& +\left(P_{X S}^{2} \times r_{X S}^{2}\right)+\left(P_{X S}^{3} \times r_{X S}^{3}\right)
\end{aligned}
$$

where

$$
\begin{aligned}
L W P= & \text { combined long-term wholesale power costs of the SLCA/IP } \\
& \text { customers, } \\
C_{S L}^{1}= & \text { SLCA/IP capacity commitment level, } \\
& \\
r_{S L}^{1}= & \text { SLCA/IP capacity sales rate, } \\
C_{S L}^{2,3}= & \text { total energy commitment level for on- and off-peak periods, } \\
r_{S L}^{2,3}= & \text { rate charged for on- and off-peak periods, } \\
P_{X S}^{1}= & \text { auxiliary supply capacity purchases, } \\
r_{X S}^{1}= & \text { auxiliary supply capacity rate, } \\
P_{X S}^{2}= & \text { auxiliary supply on-peak energy purchases, }
\end{aligned}
$$

2 For superscripted variables, 1 refers to capacity, 2 refers to on-peak energy, and 3 refers to off-peak energy. 
TABLE 9 Fixed Assumptions for SPASM

\begin{tabular}{|c|c|}
\hline Parameter $^{\mathrm{a}}$ & $\begin{array}{c}\text { Fixed } \\
\text { Assumption }\end{array}$ \\
\hline EB capacity (MW) & 0 \\
\hline EB energy (GWh) & 12.218 \\
\hline CO energy (GWh) & 44.587 \\
\hline FO energy (GWh) & 21.137 \\
\hline PV energy (GWh) & 33.336 \\
\hline $\mathrm{EB}, \mathrm{CO}, \mathrm{FO}, \mathrm{PV}$, on-peak energy ${ }^{\mathrm{b}}(\mathrm{GWh})$ & 64 \\
\hline $\mathrm{EB}, \mathrm{CO}, \mathrm{FO}, \mathrm{PV}$, off-peak energy ${ }^{\mathrm{c}}$ (GWh) & 48 \\
\hline SLCA/IP revenue requirement $(\$ / y r)$ & $98,841,010$ \\
\hline Auxiliary supply capacity $(\$ / \mathrm{kW} / \mathrm{mo})$ & 15.28 \\
\hline Auxiliary supply on-peak energy (mills/kWh) & 19.72 \\
\hline Auxiliary supply off-peak energy (mills/kWh) & 14.515 \\
\hline Customer peak demand (MW) & 8,265 \\
\hline Customer peak energy (GWh/yr) & 10,889 \\
\hline Customer off-peak energy (GWh/yr) & 32,997 \\
\hline SLCA/TP capacity purchases $(\$ / \mathrm{kW} / \mathrm{mo})$ & $6.58^{\mathrm{d}}$ \\
\hline SLCA/IP on-peak energy purchases (mills/kWh) & 18.21 \\
\hline SLCA/PP off-peak energy purchases (mills/kWh) & 14.88 \\
\hline Base case wholesale power costs $(\$ / y r)$ & $884,706,742$ \\
\hline
\end{tabular}

a $\mathrm{CO}=$ Collbran, $\mathrm{EB}=$ Elephant Butte, $\mathrm{FO}=$ Fontenelle, and $\mathrm{PV}=$ Provo.

b Source: Average Colorado (winter and summer, 21.137 and 33.336 GWh) and Rio Grande (12.218 and 44.587) multiplied by 0.5717 . Assumes constant release.

c Source: Average Colorado (winter and summer, 21.137 and 33.336 GWh) and Rio Grande (12.218 and 44.587) multiplied by 0.4283 . Assumes constant release.

d Minimum rate from iterations minus maximum rate divided by two $=(3.02+8.12) / 2$. 
$r_{X S}^{2}=$ auxiliary supply on-peak energy rate,

$P_{X S}^{3}=$ auxiliary supply off-peak energy purchases, and

$r_{X S}^{3}=$ auxiliary supply off-peak energy rate.

The rate charged for capacity in megawatts by the SLCA/IP is computed by

$$
r_{S L}^{1}=\frac{\left(\frac{R}{2}\right)}{\hat{S}^{1}}
$$

where $R$ is the revenue requirement and $\hat{S}^{1}$ is the estimated capacity sales.

The rate charged for both on-peak and off-peak energy by the SLCA/IP is calculated by

$$
r_{S L}^{2,3}=\frac{\left(\frac{R}{2}\right)}{\hat{S}^{2,3}}
$$

where $\hat{S}^{2,3}$ is the estimated energy sales in both the on- and off-peak periods.

The amount of annual revenues $(R)$ required in the representative year is computed by

$$
R=a_{R}+P E^{1}+P E^{2}+P E^{3},
$$

where

$a_{R}=$ constant revenue requirement (assumed to be fixed for this analysis),

$P E^{1}=$ is the purchased power expense for capacity,

$P E^{2}=$ is the purchased power expense for on-peak energy, and

$P E^{3}=$ is the purchased power expense for off-peak energy. 
The total annual purchased expense for capacity (in megawatts) is computed by

$$
P E^{1}=\left(C_{S L}^{1}-\sum_{f} C_{f}^{1}\right) \times r_{P}^{1}
$$

where $C_{f}^{1}$ is the project-dependent capacity at facility $f$ (see footnote) ${ }^{3}$ and $r_{P}^{1}$ is the capacity purchase rate if purchases must be made; that is, if $C_{S L}^{1}>\sum_{f} C_{f}^{1}$. If $C_{S L}^{1}<\sum_{f} C_{f}^{1}$, then the total purchased power expense is calculated by

$$
P E^{1}=\left(\sum_{f} C_{f}^{1}-C_{S L}^{1}\right) \times r_{S L}^{1}
$$

where $f$ is $\mathrm{GC}, \mathrm{FG}, \mathrm{BM}, \mathrm{CR}, \mathrm{MP}, \mathrm{EB}, \mathrm{FO}, \mathrm{CO}$, or $\mathrm{PV}$ and $r_{S L}^{1}$ is the SLCA/IP capacity sales rate, assumed to be $\$ 6.58 / \mathrm{kW} / \mathrm{mo}$.

The total annual purchased expense for on-peak energy (in gigawatt-hours) is computed by

$$
P E^{2}=\left[C_{S L}^{2}-\sum_{f} C_{f}^{2}\right] \times r_{P}^{2}
$$

where $f$ is $\mathrm{GC}, \mathrm{FG}, \mathrm{BM}, \mathrm{CR}, \mathrm{MP}, \mathrm{EB}, \mathrm{FO}, \mathrm{CO}$, or $\mathrm{PV}$ and $r_{P}^{2}$ is the on-peak energy purchase rate.

The total annual purchased expense for off-peak energy (in gigawatt-hours) is computed by

$$
P E^{3}=\left[C_{S L}^{3}-\sum_{f} C_{f}^{3}\right] \times r_{P}^{3}
$$

where $f$ is $\mathrm{GC}, \mathrm{FG}, \mathrm{BM}, \mathrm{CR}, \mathrm{MP}, \mathrm{EB}, \mathrm{FO}, \mathrm{CO}$, or $\mathrm{PV}$ and $r_{P}^{3}$ is the off-peak energy purchase rate.

3 Variables describing the facilities Glen Canyon, Flaming Gorge, Blue Mesa, Crystal, Morrow Point, Elephant Butte, Fontenelle, Collbran, and Provo are denoted by GC, FG, BM, CR, MP, EB, FO, CO, and PV, respectively. 
The estimated annual capacity purchases of SLCA/IP customers from auxiliary supply are computed by

$$
S_{X}^{1}=C P D^{1}-C_{S L}^{1}
$$

where $C P D^{l}$ is the customers' peak demand and $S_{X}^{1}$ is the capacity sales from auxiliary suppliers.

The estimated annual sales of auxiliary suppliers' on-peak energy to SLCA/IP customers are computed by

$$
S_{X}^{2}=C E N^{2}-C_{S L}^{2}
$$

where $C E N^{2}$ is the customers' on-peak energy need and $C_{S L}^{2}$ is the estimated annual on-peak energy commitment level to SLCA/IP customers, computed by

$$
C_{S L}^{2}=C_{S L}^{1} \times M S R \times 3,752
$$

where MSR is the SLCA/IP customers' minimum schedule requirement.

The estimated annual sales of auxiliary suppliers' off-peak energy to SLCA/IP customers are computed by

$$
S_{X}^{3}=C E N^{3}-C_{S L}^{3}
$$

where $C E N^{3}$ is the customers' off-peak energy need. 


\section{RESULTS}

Summary statistics in Table 10 describe the distributional characteristics of each power marketing alternative. Figures 2-9 illustrate the frequency distributions for each marketing alternative. The input values into SPASM were summarized in Table 1.

TABLE 10 Summary Statistics for the Power Marketing Alternatives

\begin{tabular}{|c|c|c|c|c|c|c|c|c|}
\hline \multirow[b]{2}{*}{ Statistic } & \multicolumn{8}{|c|}{ Value per Power Marketing Alternative $\left(10^{6} \$\right.$ except first row) } \\
\hline & All & NA & 1 & 2 & 3 & 4 & 5 & 6 \\
\hline Number of observations & 784 & 112 & 112 & 112 & 112 & 112 & 112 & 112 \\
\hline Minimum & 1,947 & 1,963 & 1,947 & 1,998 & 1,999 & 2,078 & 2,032 & 2,008 \\
\hline Maximum & 2,179 & 2,120 & 2,109 & 2,160 & 2,152 & 2,179 & 2,138 & 2,144 \\
\hline Mean & 2,073 & 2,045 & 2,033 & 2,084 & 2,077 & 2,124 & 2,079 & 2,072 \\
\hline Median & 2,070 & 2,048 & 2,037 & 2,088 & 2,080 & 2,124 & 2,078 & 2,071 \\
\hline Standard deviation & 49 & 46 & 46 & 46 & 45 & 26 & 28 & 40 \\
\hline $\begin{array}{l}\text { Average difference from } \\
\text { baseline }\end{array}$ & 1,189 & 1,160 & 1,148 & 1,199 & 1,192 & 1,239 & 1,195 & 1,187 \\
\hline $\begin{array}{l}\text { Standard deviation of } \\
\text { difference from } \\
\text { baseline }\end{array}$ & 49 & 46 & 46 & 46 & 45 & 26 & 28 & 40 \\
\hline
\end{tabular}




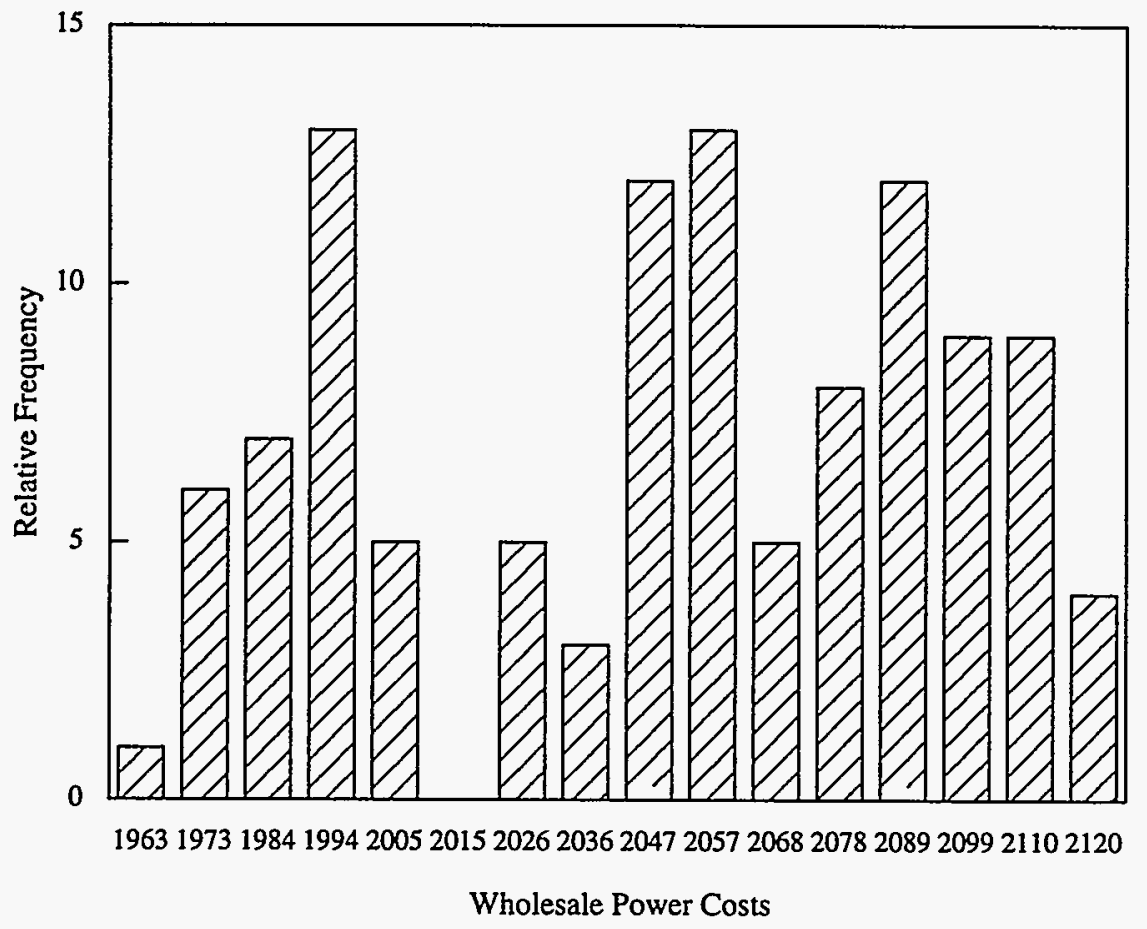

FIGURE 2 Frequency Distribution of Wholesale Power Costs $\left(10^{6} \$ / y r\right)$ for the No Action Alternative

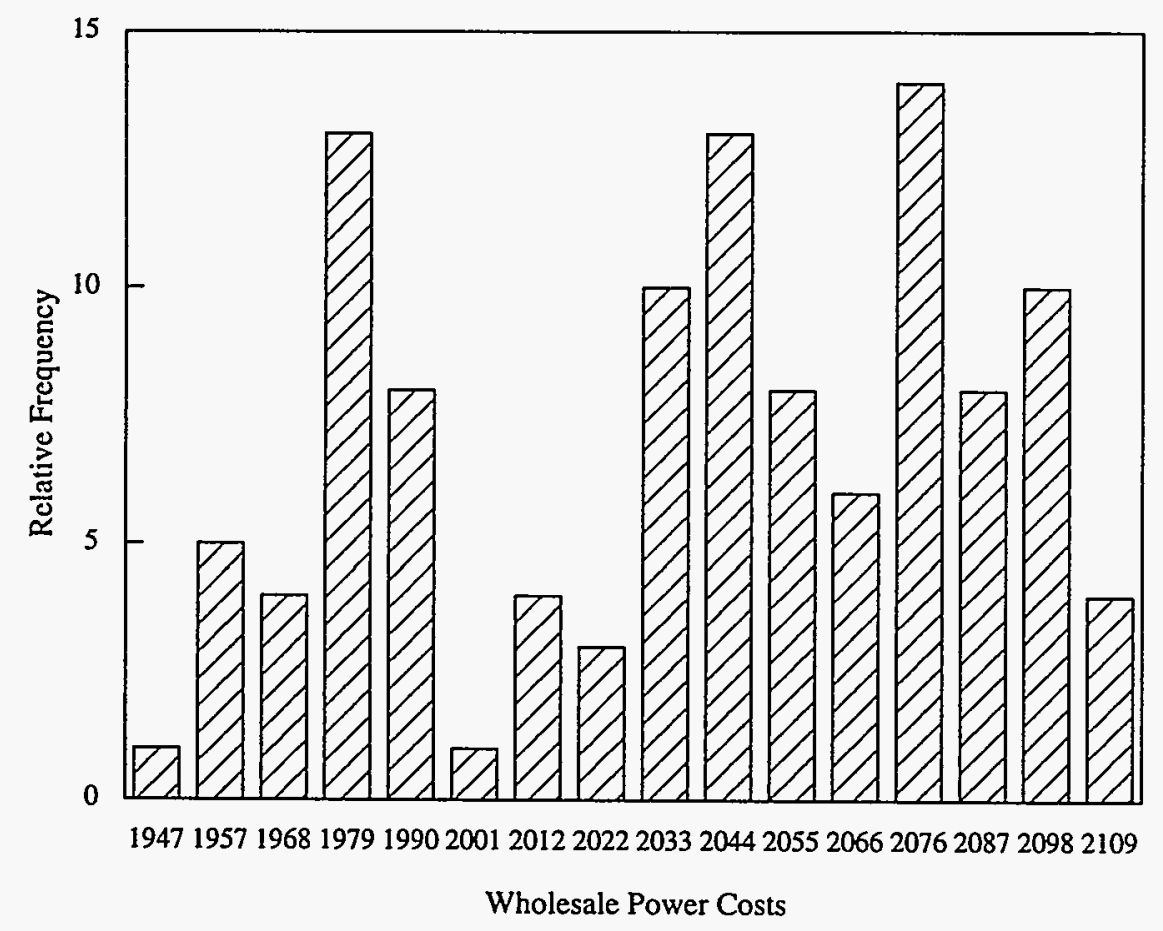

FIGURE 3 Frequency Distribution of Wholesale Power Costs $\left(10^{6} \$ / y r\right)$ for Marketing Alternative 1 


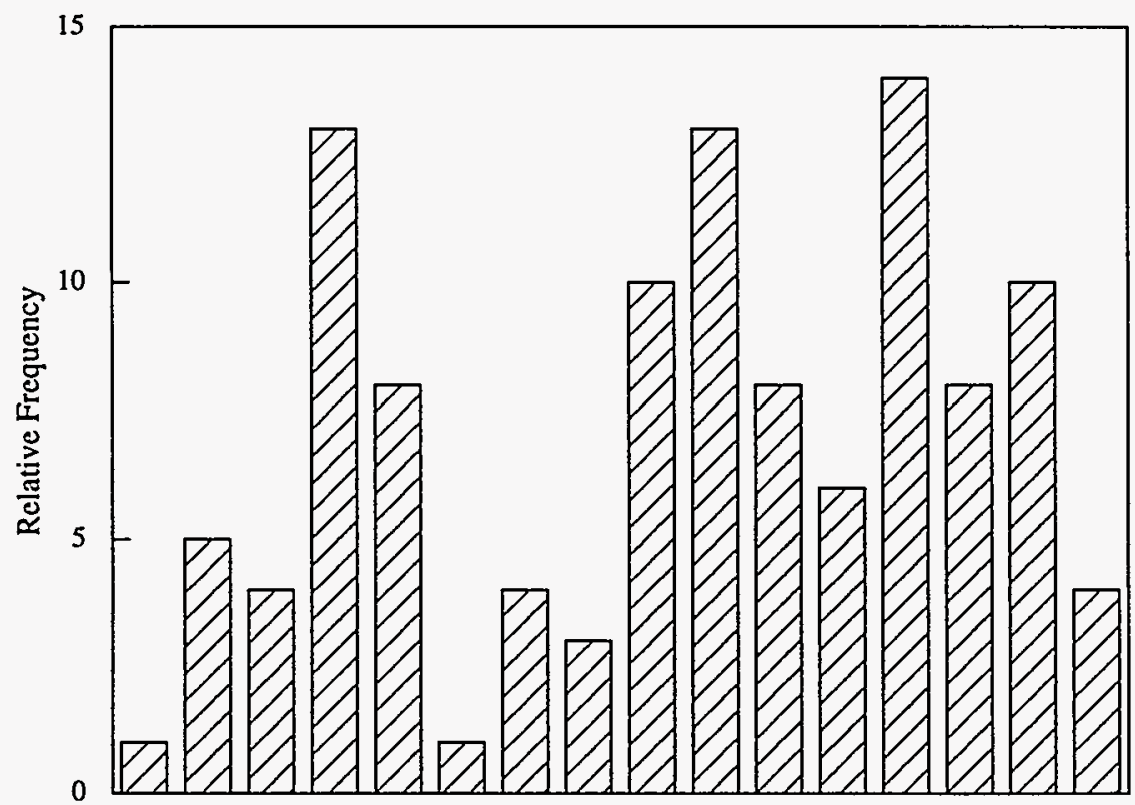

1998200920192030204120522063207320842095210621172128213821492160

Wholesale Power Costs

FIGURE 4 Frequency Distribution of Wholesale Power Costs $\left(10^{6} \$ / y r\right)$ for Marketing Alternative 2

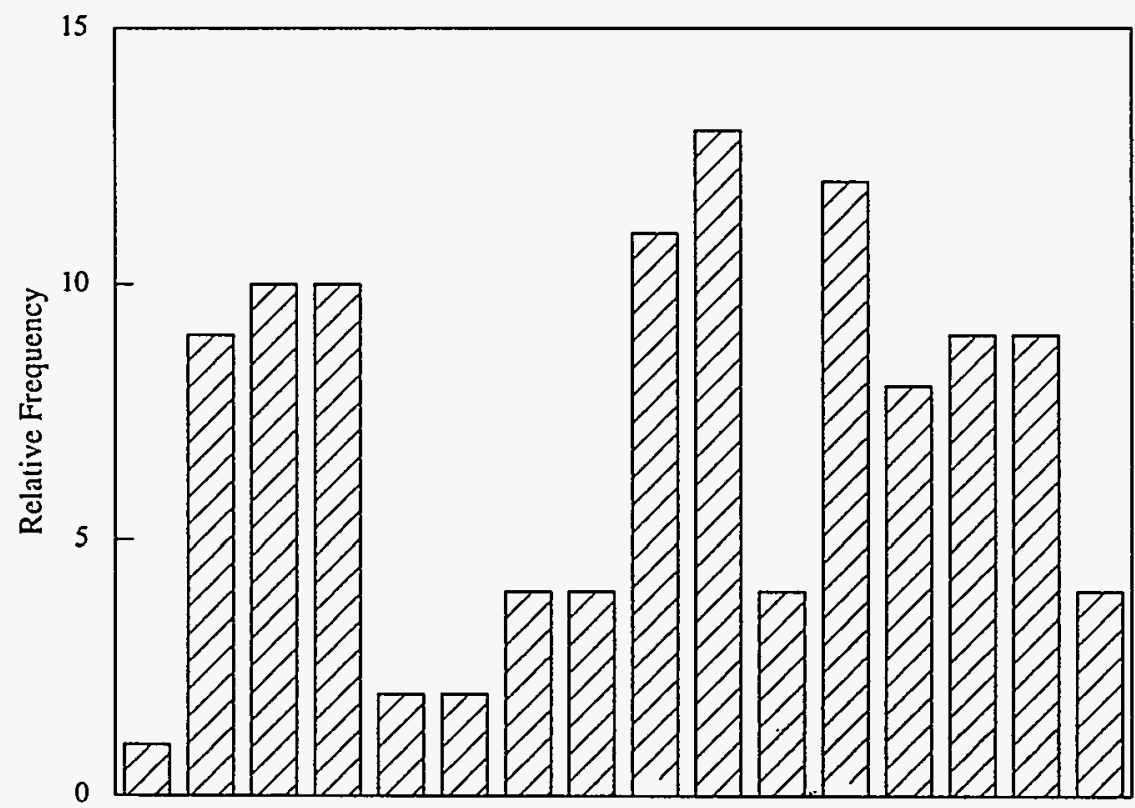

1999201020202030204020502061207120812091210121112122213221422152

Wholesale Power Costs

FIGURE 5 Frequency Distribution of Wholesale-Power Costs $\left(10^{6} \$ / y r\right)$ for Marketing Alternative 3 


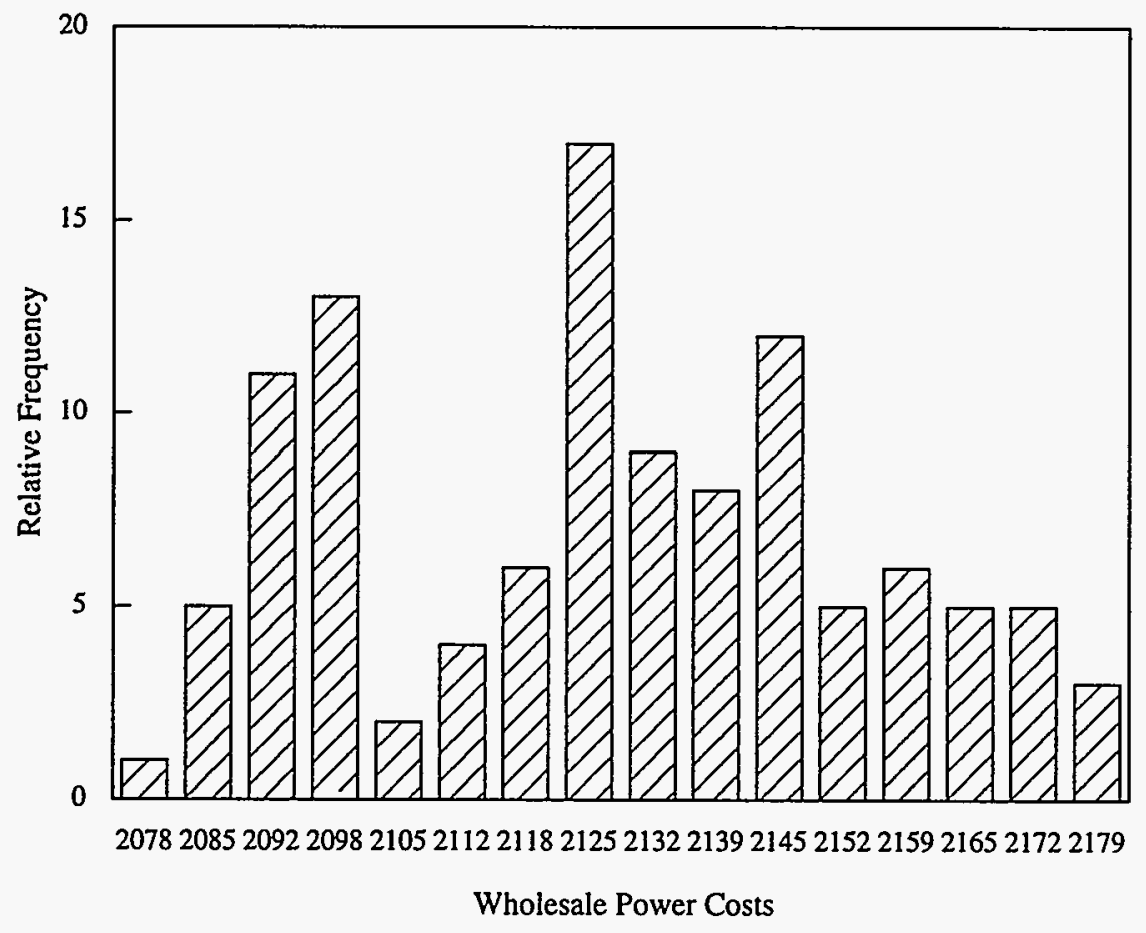

FIGURE 6 Frequency Distribution of Wholesale Power Costs $\left(10^{6} \$ / y r\right)$ for Marketing Alternative 4

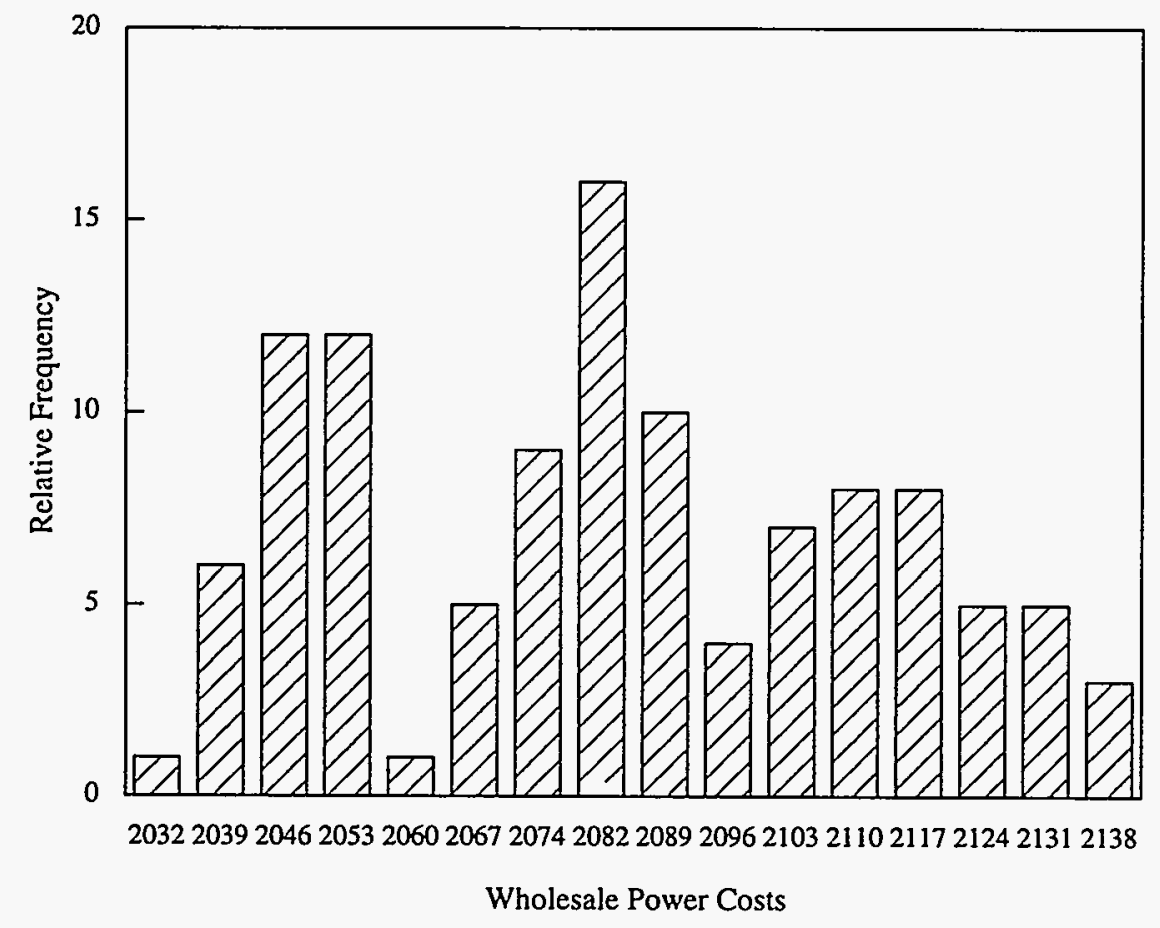

FIGURE 7 Frequency Distribution of Wholesale Power Costs $\left(10^{6} \$ / y r\right)$ for Marketing Alternative 5 


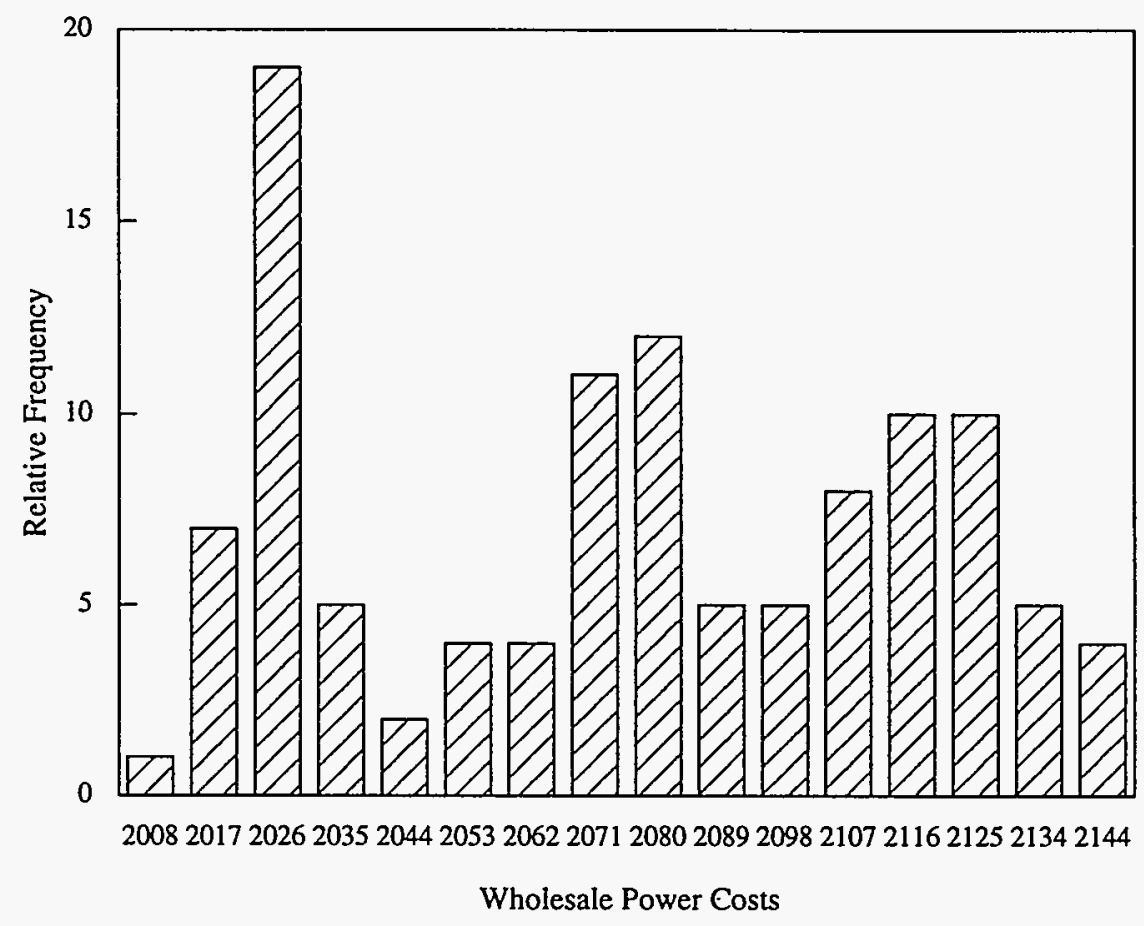

FIGURE 8 Frequency Distribution of Wholesale Power Costs $\left(10^{6} \$ / y r\right)$ for Marketing Alternative 6

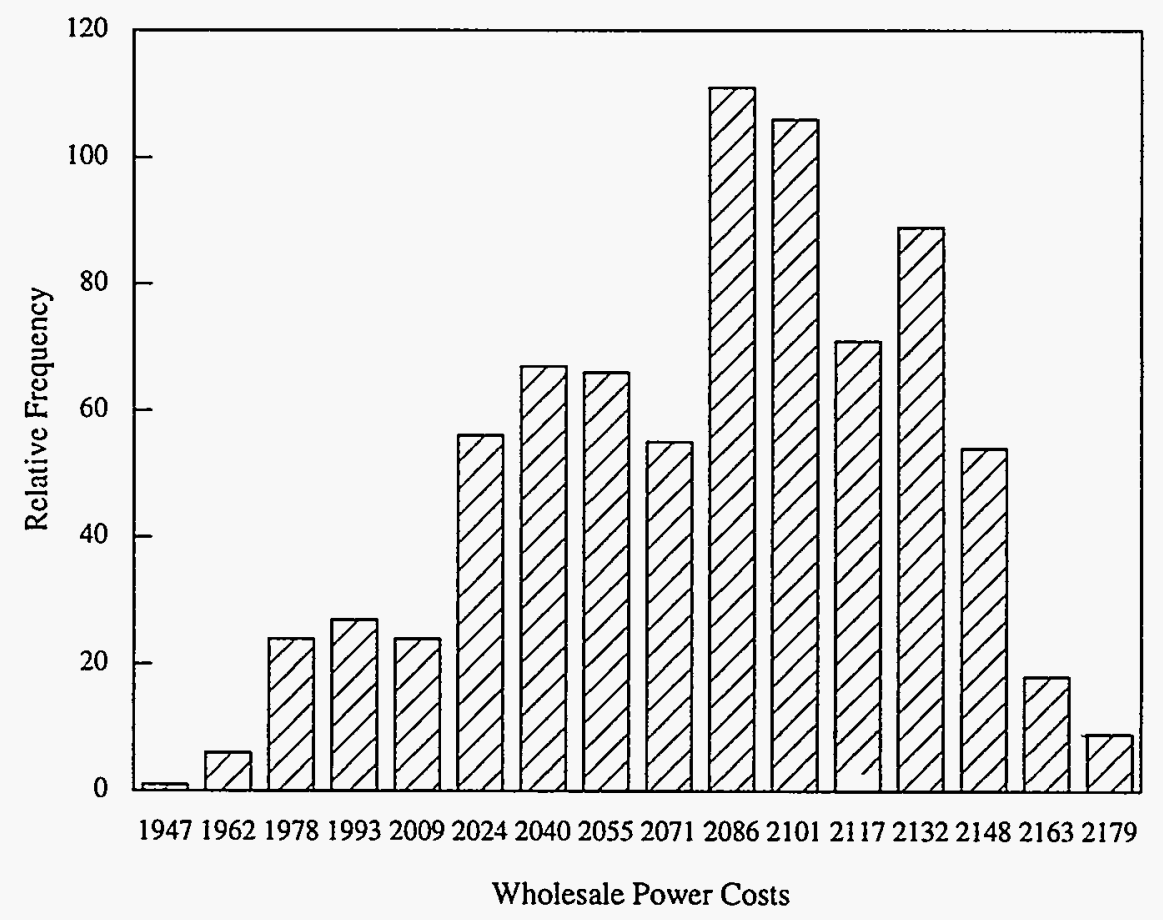

FIGURE 9 Frequency Distribution of Wholesale Power Costs $\left(10^{6} \$ / y r\right)$ for All Marketing Alternatives 


\section{SELECTION OF POWER MARKETING ALTERNATIVES AND DAM OPERATIONAL SCENARIOS}

\subsection{SELECTION OF POWER MARKETING ALTERNATIVES}

The National Environmental Policy Act (NEPA) requires that the No Action Alternative (NA) must be included as an alternative for consideration. The other marketing alternatives selected are those at the extreme ends of the capacity/energy ratio. Specifically, one alternative includes the highest capacity and lowest energy (Alternative 2). Another includes the lowest energy and lowest capacity (Alternative 4). Finally, another alternative includes the highest energy and lowest capacity (Alternative 5). The alternative with the highest capacity and energy is relatively close to the No Action Alternative. The No Action Alternative and Alternatives 2, 4, and 5 were obvious selections for the alternatives to be analyzed in detail because they span the range of possibilities. The marketing alternatives selected are summarized in Table 11.

\subsection{SELECTION OF OPERATIONAL SCENARIO COMBINATIONS}

The next step was to select combinations of operational scenarios at the Flaming Gorge Dam, Glen Canyon Dam, and Aspinall Unit and match them with the marketing alternatives selected. The wholesale power costs from SPASM were used as the basis for selecting those combinations of operational scenarios that produce the (1) least costly, (2) median, and (3) most costly wholesale power. (The output data from SPASM are included in Appendix B).

The least costly, median, and most costly operational scenarios were calculated for each marketing alternative. The same combinations resulted for each marketing alternative. These combinations are shown in Table 12.

On the basis of these selection criteria, the combinations of Table 12 would have been selected for detailed study in the SLCA/IP Electric Power Marketing EIS; however, some combinations that have wholesale power costs, as estimated by SPASM, that are close to the statistical selection criteria values were more appropriate for further study than others. For example, Operational Scenario Combination 411 has a wholesale power cost that is only $\$ 7,000$ different from 
the SPASM median value under any marketing alternative. A detailed analysis of Combination 411 would allow Western to estimate the specific economic impacts of interim flows at Glen Canyon Dam. Operational Scenario Combination 111 would also be of interest to Western. This combination is close to the least costly combination estimated by SPASM and could be of interest because it presumes that the dams are operated as they were historically. This combination could be used as a historic baseline. Finally, Combination 644 was chosen because it represents steady flow at all of the dams; it is also the most costly combination estimated by SPASM. Table 13 summarizes the operational scenario combinations that were selected for detailed study in the EIS.

TABLE 12 Operational Scenario Combinations Selected on the Basis of Statistical Selection Criteria

\begin{tabular}{lccc}
\hline \multicolumn{1}{c}{ Criterion } & $\begin{array}{c}\text { Glen } \\
\text { Canyon }\end{array}$ & $\begin{array}{c}\text { Flaming } \\
\text { Gorge }\end{array}$ & Aspinall \\
\hline Least costly & 1 & 1 & 2 \\
Median value & 4 & 3 & 1 \\
Most costly & 6 & 4 & 4 \\
\hline
\end{tabular}

TABLE 13 Final Operational Scenario Combinations Selected for the EIS

\begin{tabular}{lccc}
\hline \multicolumn{1}{c}{ Criterion } & $\begin{array}{c}\text { Glen } \\
\text { Canyon }\end{array}$ & $\begin{array}{c}\text { Flaming } \\
\text { Gorge }\end{array}$ & Aspinall \\
\hline Approximately lowest cost & 1 & 1 & 1 \\
Approximate median value & 4 & 1 & 1 \\
Highest cost & 6 & 4 & 4 \\
\hline
\end{tabular}




\section{REFERENCES}

Onstad, D.O., 1993, personal communication from Onstad (Arizona Power Authority, Phoenix, Ariz.) to R.E. Fisher (Argonne National Laboratory, Argonne, Ill.).

Reclamation, 1993, Operation of Glen Canyon Dam Colorado River Storage Project, Arizona, Draft Environmental Impact Statement, U.S. Bureau of Reclamation, Salt Lake City, Utah.

U.S. Fish and Wildlife Service, 1992, "Final Biological Opinion on the Operation of Flaming Gorge Dam," Mountain-Prairie Region, Denver, Colo.

Western Area Power Administration, 1992, Non-Firm Purchases Information 1985-1992, Salt Lake City Area Office, Salt Lake City, Utah, April, pp. 1-4. 


\section{APPENDIX A:}

\section{VARIABLES WITH SOURCES AND ASSUMPTIONS}

$$
\begin{aligned}
& a_{R} \quad=\text { constant revenue requirement } \\
& C_{S L}^{1} \quad=\text { SLCAIIP capacity commitment level } \\
& C_{S L}^{2,3}=\text { total energy commitment level for on- and off-peak periods } \\
& C E N^{2}=\text { customers' on-peak energy need } \\
& C E N^{3}=\text { customers' off-peak energy need } \\
& C F_{c f s-M W}^{f}=\text { conversion factor for transforming flow in cubic feet per second to capacity in } \\
& C P D^{1} \quad=\text { customers' peak demand } \\
& f \quad=\text { index of facilities (GC, FG, BM, CR, MP, EB, FO, CO, or PV) } \\
& \text { LWP = combined long-term wholesale power costs of the SLCA/IP customers computed } \\
& M S R=\text { minimum schedule requirement } \\
& P_{X S}^{1} \quad=\text { auxiliary supply capacity purchases } \\
& P_{X S}^{2} \quad=\text { auxiliary supply on-peak energy purchases } \\
& P_{X S}^{3} \quad=\text { auxiliary supply off-peak energy purchases } \\
& P D C^{\#} \quad=\text { project-dependent capacity associated with each alternative (\#) } \\
& P E^{1} \quad=\text { purchased power expense for capacity } \\
& P E^{2} \quad=\text { purchased power expense for on-peak energy } \\
& P E^{3} \quad=\text { purchased power expense for off-peak energy } \\
& r_{P}^{1} \quad=\text { capacity purchase rate } \\
& r_{P}^{2} \quad=\text { on-peak energy purchase rate averaged from Non-Firm Purchases Information } \\
& \text { 1985-1992 (Western Area Power Administration 1992) }
\end{aligned}
$$


$r_{P}^{3}=$ off-peak energy purchase rate averaged from Non-Firm Purchases Information 1985-1992 (Western Area Power Administration 1992)

$r_{S L}^{1}=$ SLCA/IP capacity sales rate, which is assumed to $\$ 6.58 / \mathrm{kW} / \mathrm{mo}$

$r_{S L}^{2,3}=$ rate charged for on- and off-peak periods

$r_{X S}^{1} \quad=$ auxiliary supply capacity rate from Onstad (1993). WQ1 average of winter and summer for small customers: $(17.56 \times 0.5)+(10.00 \times 0.5)$

$r_{X S}^{2}=$ auxiliary supply on-peak energy rate: $(21.23 \times 0.5)+(18.21 \times 0.5)=19.72$

$r_{X S}^{3}=$ auxiliary supply off-peak energy rate: $(14.15 \times 0.5)+(14.88 \times 0.5)=14.515$

$R \quad \quad=$ revenue requirement

$\hat{S}^{1} \quad=$ estimated capacity sales

$\hat{S}^{2,3}=$ estimated energy sales in both the on- and off-peak periods

$S_{X}^{1} \quad=$ capacity sales from auxiliary suppliers

$S_{X}^{2} \quad=$ on-peak energy sales from auxiliary suppliers

$S_{X}^{3} \quad=$ off-peak energy sales from auxiliary suppliers

TEC = total energy commitment 


\section{APPENDIX B:}

SPASM ESTIMATES OF WHOLESALE POWER COSTS OF MARKETING ALTERNATIVE/OPERATIONAL SCENARIO COMBINATIONS

TABLE B.1 SPASM Estimates of Wholesale Power Costs

\begin{tabular}{|c|c|c|c|c|}
\hline $\begin{array}{l}\text { Marketing } \\
\text { Alternative }\end{array}$ & $\begin{array}{c}\text { Glen Canyon } \\
\text { Operational } \\
\text { Scenario } \\
\end{array}$ & $\begin{array}{c}\text { Flaming Gorge } \\
\text { Operational } \\
\text { Scenario } \\
\end{array}$ & $\begin{array}{c}\text { Aspinall } \\
\text { Operational } \\
\text { Scenario } \\
\end{array}$ & $\begin{array}{c}\text { SPASM Estimates } \\
\text { of Wholesale } \\
\text { Power Costs }\end{array}$ \\
\hline $\mathrm{NA}$ & 1 & 1 & 1 & $\$ 1,977,542,297$ \\
\hline NA & 1 & 1 & 2 & $\$ 1,962,547,043$ \\
\hline NA & 1 & 1 & 3 & $\$ 1,979,905,136$ \\
\hline NA & 1 & 1 & 4 & $\$ 1,986,063,227$ \\
\hline $\mathrm{NA}$ & 1 & 2 & 1 & $\$ 1,977,518,321$ \\
\hline NA & 1 & 2 & 2 & $\$ 1,962,523,067$ \\
\hline $\mathrm{NA}$ & 1 & 2 & 3 & $\$ 1,979,881,160$ \\
\hline NA & 1 & 2 & 4 & $\$ 1,986,039,251$ \\
\hline NA & 1 & 3 & 1 & $\$ 1,984,500,288$ \\
\hline NA & 1 & 3 & 2 & $\$ 1,966,069,680$ \\
\hline $\mathrm{NA}$ & 1 & 3 & 3 & $\$ 1,986,863,127$ \\
\hline NA & 1 & 3 & 4 & $\$ 1,993,021,218$ \\
\hline NA & 1 & 4 & 1 & $\$ 1,990,842,338$ \\
\hline NA & 1 & 4 & 2 & $\$ 1,971,435,158$ \\
\hline NA & 1 & 4 & 3 & $\$ 1,993,205,177$ \\
\hline $\mathrm{NA}$ & 1 & 4 & 4 & $\$ 1,999,363,268$ \\
\hline NA & 2 & 1 & 1 & $\$ 1,981,344,628$ \\
\hline NA & 2 & 1 & 2 & $\$ 1,964,500,415$ \\
\hline NA & 2 & 1 & 3 & $\$ 1,983,707,467$ \\
\hline NA & 2 & 1 & 4 & $\$ 1,989,865,558$ \\
\hline NA & 2 & 2 & 1 & $\$ 1,981,320,652$ \\
\hline NA & 2 & 2 & 2 & $\$ 1,964,476,439$ \\
\hline NA & 2 & 2 & 3 & $\$ 1,983,683,491$ \\
\hline NA & 2 & 2 & 4 & $\$ 1,989,841,582$ \\
\hline
\end{tabular}


TABLE B.1 (Cont.)

\begin{tabular}{|c|c|c|c|c|}
\hline $\begin{array}{l}\text { Marketing } \\
\text { Alternative }\end{array}$ & $\begin{array}{c}\text { Glen Canyon } \\
\text { Operational } \\
\text { Scenario } \\
\end{array}$ & $\begin{array}{c}\text { Flaming Gorge } \\
\text { Operational } \\
\text { Scenario } \\
\end{array}$ & $\begin{array}{c}\text { Aspinall } \\
\text { Operational } \\
\text { Scenario } \\
\end{array}$ & $\begin{array}{c}\text { SPASM Estimates } \\
\text { of Wholesale } \\
\text { Power Costs } \\
\end{array}$ \\
\hline NA & 2 & 3 & 1 & $\$ 1,988,302,620$ \\
\hline NA & 2 & 3 & 2 & $\$ 1,968,895,440$ \\
\hline NA & 2 & 3 & 3 & $\$ 1,990,665,459$ \\
\hline NA & 2 & 3 & 4 & $\$ 1,996,823,550$ \\
\hline NA & 2 & 4 & 1 & $\$ 1,994,644,669$ \\
\hline NA & 2 & 4 & 2 & $\$ 1,975,237,489$ \\
\hline NA & 2 & 4 & 3 & $\$ 1,997,007,508$ \\
\hline NA & 2 & 4 & 4 & $\$ 2,003,165,599$ \\
\hline NA & 3 & 1 & 1 & $\$ 2,036,901,750$ \\
\hline NA & 3 & 1 & 2 & $\$ 2,017,494,570$ \\
\hline NA & 3 & 1 & 3 & $\$ 2,039,264,589$ \\
\hline NA & 3 & 1 & 4 & $\$ 2,045,422,680$ \\
\hline NA & 3 & 2 & 1 & $\$ 2,036,877,774$ \\
\hline NA & 3 & 2 & 2 & $\$ 2,017,470,594$ \\
\hline NA & 3 & 2 & 3 & $\$ 2,039,240,613$ \\
\hline NA & 3 & 2 & 4 & $\$ 2,045,398,704$ \\
\hline NA & 3 & 3 & 1 & $\$ 2,043,859,742$ \\
\hline NA & 3 & 3 & 2 & $\$ 2,024,452,562$ \\
\hline NA & 3 & 3 & 3 & $\$ 2,046,222,581$ \\
\hline NA & 3 & 3 & 4 & $\$ 2,052,380,672$ \\
\hline NA & 3 & 4 & 1 & $\$ 2,050,201,791$ \\
\hline NA & 3 & 4 & 2 & $\$ 2,030,794,611$ \\
\hline NA & 3 & 4 & 3 & $\$ 2,052,564,630$ \\
\hline NA & 3 & 4 & 4 & $\$ 2,058,722,721$ \\
\hline NA & 4 & 1 & 1 & $\$ 2,041,106,432$ \\
\hline NA & 4 & 1 & 2 & $\$ 2,021,699,252$ \\
\hline NA & 4 & 1 & 3 & $\$ 2,043,469,271$ \\
\hline NA & 4 & 1 & 4 & $\$ 2,049,627,362$ \\
\hline NA & 4 & 2 & 1 & $\$ 2,041,082,456$ \\
\hline $\mathrm{NA}$ & 4 & 2 & $2^{\circ}$ & $\$ 2,021,675,276$ \\
\hline NA & 4 & 2 & 3 & $\$ 2,043,445,295$ \\
\hline NA & 4 & 2 & 4 & $\$ 2,049,603,386$ \\
\hline
\end{tabular}


TABLE B.1 (Cont.)

\begin{tabular}{|c|c|c|c|c|}
\hline $\begin{array}{l}\text { Marketing } \\
\text { Alternative }\end{array}$ & $\begin{array}{c}\text { Glen Canyon } \\
\text { Operational } \\
\text { Scenario } \\
\end{array}$ & $\begin{array}{c}\text { Flaming Gorge } \\
\text { Operational } \\
\text { Scenario } \\
\end{array}$ & $\begin{array}{c}\text { Aspinall } \\
\text { Operational } \\
\text { Scenario } \\
\end{array}$ & $\begin{array}{c}\text { SPASM Estimates } \\
\text { of Wholesale } \\
\text { Power Costs } \\
\end{array}$ \\
\hline NA & 4 & 3 & 1 & $\$ 2,048,064,424$ \\
\hline NA & 4 & 3 & 2 & $\$ 2,028,657,244$ \\
\hline NA & 4 & 3 & 3 & $\$ 2,050,427,263$ \\
\hline NA & 4 & 3 & 4 & $\$ 2,056,585,354$ \\
\hline NA & 4 & 4 & 1 & $\$ 2,054,406,473$ \\
\hline NA & 4 & 4 & 2 & $\$ 2,034,999,293$ \\
\hline NA & 4 & 4 & 3 & $\$ 2,056,769,312$ \\
\hline NA & 4 & 4 & 4 & $\$ 2,062,927,403$ \\
\hline NA & 5 & 1 & 1 & $\$ 2,069,564,697$ \\
\hline NA & 5 & 1 & 2 & $\$ 2,050,157,517$ \\
\hline NA & 5 & 1 & 3 & $\$ 2,071,927,536$ \\
\hline NA & 5 & 1 & 4 & $\$ 2,078,085,627$ \\
\hline NA & 5 & 2 & 1 & $\$ 2,069,540,721$ \\
\hline NA & 5 & 2 & 2 & $\$ 2,050,133,541$ \\
\hline NA & 5 & 2 & 3 & $\$ 2,071,903,560$ \\
\hline NA & 5 & 2 & 4 & $\$ 2,078,061,651$ \\
\hline NA & 5 & 3 & 1 & $\$ 2,076,522,688$ \\
\hline NA & 5 & 3 & 2 & $\$ 2,057,115,508$ \\
\hline NA & 5 & 3 & 3 & $\$ 2,078,885,527$ \\
\hline $\mathrm{NA}$ & 5 & 3 & 4 & $\$ 2,085,043,618$ \\
\hline NA & 5 & 4 & 1 & $\$ 2,082,864,738$ \\
\hline NA & 5 & 4 & 2 & $\$ 2,063,457,558$ \\
\hline NA & 5 & 4 & 3 & $\$ 2,085,227,577$ \\
\hline $\mathrm{NA}$ & 5 & 4 & 4 & $\$ 2,091,385,668$ \\
\hline $\mathrm{NA}$ & 6 & 1 & 1 & $\$ 2,098,580,697$ \\
\hline NA & 6 & 1 & 2 & $\$ 2,079,173,517$ \\
\hline $\mathrm{NA}$ & 6 & 1 & 3 & $\$ 2,100,943,536$ \\
\hline $\mathrm{NA}$ & 6 & 1 & 4 & $\$ 2,107,101,627$ \\
\hline NA & 6 & 2 & 1 & $\$ 2,098,556,721$ \\
\hline NA & 6 & 2 & 2 & $\$ 2,079,149,541$ \\
\hline NA & 6 & 2 & 3 & $\$ 2,100,919,560$ \\
\hline NA & 6 & 2 & 4 & $\$ 2,107,077,651$ \\
\hline
\end{tabular}


TABLE B.1 (Cont.)

\begin{tabular}{|c|c|c|c|c|}
\hline $\begin{array}{l}\text { Marketing } \\
\text { Alternative } \\
\end{array}$ & $\begin{array}{c}\text { Glen Canyon } \\
\text { Operational } \\
\text { Scenario } \\
\end{array}$ & $\begin{array}{c}\text { Flaming Gorge } \\
\text { Operational } \\
\text { Scenario } \\
\end{array}$ & $\begin{array}{c}\text { Aspinall } \\
\text { Operational } \\
\text { Scenario } \\
\end{array}$ & $\begin{array}{c}\text { SPASM Estimates } \\
\text { of Wholesale } \\
\text { Power Costs }\end{array}$ \\
\hline NA & 6 & 3 & 1 & $\$ 2,105,538,688$ \\
\hline NA & 6 & 3 & 2 & $\$ 2,086,131,508$ \\
\hline NA & 6 & 3 & 3 . & $\$ 2,107,901,527$ \\
\hline $\mathrm{NA}$ & 6 & 3 & 4 & $\$ 2,114,059,618$ \\
\hline NA & 6 & 4 & 1 & $\$ 2,111,880,738$ \\
\hline NA & 6 & 4 & 2 & $\$ 2,092,473,558$ \\
\hline NA & 6 & 4 & 3 & $\$ 2,114,243,577$ \\
\hline NA & 6 & 4 & 4 & $\$ 2,120,401,668$ \\
\hline NA & 7 & 1 & 1 & $\$ 2,085,554,697$ \\
\hline NA & 7 & 1 & 2 & $\$ 2,066,147,517$ \\
\hline NA & 7 & 1 & 3 & $\$ 2,087,917,536$ \\
\hline NA & 7 & 1 & 4 & $\$ 2,094,075,627$ \\
\hline NA & 7 & 2 & 1 & $\$ 2,085,530,721$ \\
\hline NA & 7 & 2 & 2 & $\$ 2,066,123,541$ \\
\hline $\mathrm{NA}$ & 7 & 2 & 3 & $\$ 2,087,893,560$ \\
\hline NA & 7 & 2 & 4 & $\$ 2,094,051,651$ \\
\hline NA & 7 & 3 & 1 & $\$ 2,092,512,688$ \\
\hline NA & 7 & 3 & 2 & $\$ 2,073,105,508$ \\
\hline NA & 7 & 3 & 3 & $\$ 2,094,875,527$ \\
\hline NA & 7 & 3 & 4 & $\$ 2,101,033,618$ \\
\hline $\mathrm{NA}$ & 7 & 4 & 1 & $\$ 2,098,854,738$ \\
\hline NA & 7 & 4 & 2 & $\$ 2,079,447,558$ \\
\hline NA & 7 & 4 & 3 & $\$ 2,101,217,577$ \\
\hline NA & 7 & 4 & 4 & $\$ 2,107,375,668$ \\
\hline 1 & 1 & 1 & 1 & $\$ 1,966,070,849$ \\
\hline 1 & 1 & 1 & $2 \therefore$ & $\$ 1,946,663,669$ \\
\hline 1 & 1 & 1 & 3 & $\$ 1,968,433,688$ \\
\hline 1 & 1 & 1 & 4 & $\$ 1,974,591,779$ \\
\hline 1 & 1 & 2 & 1 & $\$ 1,966,046,873$ \\
\hline 1 & 1 & 2 & 2 & $\$ 1,946,639,693$ \\
\hline 1 & 1 & 2 & 3 & $\$ 1,968,409,712$ \\
\hline 1 & 1 & 2 & 4 & $\$ 1,974,567,803$ \\
\hline
\end{tabular}


TABLE B.1 (Cont.)

\begin{tabular}{|c|c|c|c|c|}
\hline $\begin{array}{l}\text { Marketing } \\
\text { Alternative } \\
\end{array}$ & $\begin{array}{c}\text { Glen Canyon } \\
\text { Operational } \\
\text { Scenario } \\
\end{array}$ & $\begin{array}{c}\text { Flaming Gorge } \\
\text { Operational } \\
\text { Scenario } \\
\end{array}$ & $\begin{array}{c}\text { Aspinall } \\
\text { Operational } \\
\text { Scenario } \\
\end{array}$ & $\begin{array}{c}\text { SPASM Estimates } \\
\text { of Wholesale } \\
\text { Power Costs } \\
\end{array}$ \\
\hline 1 & 1 & 3 & 1 & $\$ 1,973,028,840$ \\
\hline 1 & 1 & 3 & 2 & $\$ 1,953,621,660$ \\
\hline 1 & 1 & 3 & 3 & $\$ 1,975,391,679$ \\
\hline 1 & 1 & 3 & 4 & $\$ 1,981,549,770$ \\
\hline 1 & 1 & 4 & 1 & $\$ 1,979,370,890$ \\
\hline 1 & 1 & 4 & 2 & $\$ 1,959,963,710$ \\
\hline 1 & 1 & 4 & 3 & $\$ 1,981,733,729$ \\
\hline 1 & 1 & 4 & 4 & $\$ 1,987,891,820$ \\
\hline 1 & 2 & 1 & 1 & $\$ 1,969,873,180$ \\
\hline 1 & 2 & 1 & 2 & $\$ 1,950,466,000$ \\
\hline 1 & 2 & 1 & 3 & $\$ 1,972,236,019$ \\
\hline 1 & 2 & 1 & 4 & $\$ 1,978,394,110$ \\
\hline 1 & 2 & 2 & 1 & $\$ 1,969,849,204$ \\
\hline 1 & 2 & 2 & 2 & $\$ 1,950,442,024$ \\
\hline 1 & 2 & 2 & 3 & $\$ 1,972,212,043$ \\
\hline 1 & 2 & 2 & 4 & $\$ 1,978,370,134$ \\
\hline 1 & 2 & 3 & 1 & $\$ 1,976,831,172$ \\
\hline 1 & 2 & 3 & 2 & $\$ 1,957,423,992$ \\
\hline 1 & 2 & 3 & 3 & $\$ 1,979,194,011$ \\
\hline 1 & 2 & 3 & 4 & $\$ 1,985,352,102$ \\
\hline 1 & 2 & 4 & 1 & $\$ 1,983,173,221$ \\
\hline 1 & 2 & 4 & 2 & $\$ 1,963,766,041$ \\
\hline 1 & 2 & 4 & 3 & $\$ 1,985,536,060$ \\
\hline 1 & 2 & 4 & 4 & $\$ 1,991,694,151$ \\
\hline 1 & 3 & 1 & 1 & $\$ 2,025,430,302$ \\
\hline 1 & 3 & 1 & 2 & $\$ 2,006,023,122$ \\
\hline 1 & 3 & 1 & 3 & $\$ 2,027,793,141$ \\
\hline 1 & 3 & 1 & 4 & $\$ 2,033,951,232$ \\
\hline 1 & 3 & 2 & 1 & $\$ 2,025,406,326$ \\
\hline 1 & 3 & 2 & 2 & $\$ 2,005,999,146$ \\
\hline 1 & 3 & 2 & 3 & $\$ 2,027,769,165$ \\
\hline 1 & 3 & 2 & 4 & $\$ 2,033,927,256$ \\
\hline
\end{tabular}


TABLE B.1 (Cont.)

\begin{tabular}{|c|c|c|c|c|}
\hline $\begin{array}{l}\text { Marketing } \\
\text { Alternative } \\
\end{array}$ & $\begin{array}{c}\text { Glen Canyon } \\
\text { Operational } \\
\text { Scenario } \\
\end{array}$ & $\begin{array}{c}\text { Flaming Gorge } \\
\text { Operational } \\
\text { Scenario } \\
\end{array}$ & $\begin{array}{c}\text { Aspinall } \\
\text { Operational } \\
\text { Scenario } \\
\end{array}$ & $\begin{array}{c}\text { SPASM Estimates } \\
\text { of Wholesale } \\
\text { Power Costs }\end{array}$ \\
\hline 1 & 3 & 3 & 1 & $\$ 2,032,388,294$ \\
\hline 1 & 3 & 3 & 2 & $\$ 2,012,981,114$ \\
\hline 1 & 3 & 3 & 3 & $\$ 2,034,751,133$ \\
\hline 1 & 3 & 3 & 4 & $\$ 2,040,909,224$ \\
\hline 1 & 3 & 4 & 1 & $\$ 2,038,730,343$ \\
\hline 1 & 3 & 4 & 2 & $\$ 2,019,323,163$ \\
\hline 1 & 3 & 4 & 3 & $\$ 2,041,093,182$ \\
\hline 1 & 3 & 4 & 4 & $\$ 2,047,251,273$ \\
\hline 1 & 4 & 1 & 1 & $\$ 2,029,634,984$ \\
\hline 1 & 4 & 1 & 2 & $\$ 2,010,227,804$ \\
\hline 1 & 4 & 1 & 3 & $\$ 2,031,997,823$ \\
\hline 1 & 4 & 1 & 4 & $\$ 2,038,155,914$ \\
\hline 1 & 4 & 2 & 1 & $\$ 2,029,611,008$ \\
\hline 1 & 4 & 2 & 2 & $\$ 2,010,203,828$ \\
\hline 1 & 4 & 2 & 3 & $\$ 2,031,973,847$ \\
\hline 1 & 4 & 2 & 4 & $\$ 2,038,131,938$ \\
\hline 1 & 4 & 3 & 1 & $\$ 2,036,592,976$ \\
\hline 1 & 4 & 3 & 2 & $\$ 2,017,185,796$ \\
\hline 1 & 4 & 3 & 3 & $\$ 2,038,955,815$ \\
\hline 1 & 4 & 3 & 4 & $\$ 2,045,113,906$ \\
\hline 1 & 4 & 4 & 1 & $\$ 2,042,935,025$ \\
\hline 1 & 4 & 4 & 2 & $\$ 2,023,527,845$ \\
\hline 1 & 4 & 4 & 3 & $\$ 2,045,297,864$ \\
\hline 1 & 4 & 4 & 4 & $\$ 2,051,455,955$ \\
\hline 1 & 5 & 1 & 1 & $\$ 2,058,093,249$ \\
\hline 1 & 5 & 1 & 2 & $\$ 2,038,686,069$ \\
\hline 1 & 5 & 1 & 3 & $\$ 2,060,456,088$ \\
\hline 1 & 5 & 1 & 4 & $\$ 2,066,614,179$ \\
\hline 1 & 5 & 2 & 1 & $\$ 2,058,069,273$ \\
\hline 1 & 5 & 2 & 2 & $\$ 2,038,662,093$ \\
\hline 1 & 5 & 2 & 3 & $\$ 2,060,432,112$ \\
\hline 1 & 5 & 2 & 4 & $\$ 2,066,590,203$ \\
\hline
\end{tabular}


TABLE B.1 (Cont.)

\begin{tabular}{|c|c|c|c|c|}
\hline $\begin{array}{l}\text { Marketing } \\
\text { Alternative } \\
\end{array}$ & $\begin{array}{c}\text { Glen Canyon } \\
\text { Operational } \\
\text { Scenario } \\
\end{array}$ & $\begin{array}{c}\text { Flaming Gorge } \\
\text { Operational } \\
\text { Scenario } \\
\end{array}$ & $\begin{array}{c}\text { Aspinall } \\
\text { Operational } \\
\text { Scenario } \\
\end{array}$ & $\begin{array}{c}\text { SPASM Estimates } \\
\text { of Wholesale } \\
\text { Power Costs } \\
\end{array}$ \\
\hline 1 & 5 & 3 & 1 & $\$ 2,065,051,240$ \\
\hline 1 & 5 & 3 & 2 & $\$ 2,045,644,060$ \\
\hline 1 & 5 & 3 & 3 & $\$ 2,067,414,079$ \\
\hline 1 & 5 & 3 & 4 & $\$ 2,073,572,170$ \\
\hline 1 & 5 & 4 & 1 & $\$ 2,071,393,290$ \\
\hline 1 & 5 & 4 & 2 & $\$ 2,051,986,110$ \\
\hline 1 & 5 & 4 & 3 & $\$ 2,073,756,129$ \\
\hline 1 & 5 & 4 & 4 & $\$ 2,079,914,220$ \\
\hline 1 & 6 & 1 & 1 & $\$ 2,087,109,249$ \\
\hline 1 & 6 & 1 & 2 & $\$ 2,067,702,069$ \\
\hline 1 & 6 & 1 & 3 & $\$ 2,089,472,088$ \\
\hline 1 & 6 & 1 & 4 & $\$ 2,095,630,179$ \\
\hline 1 & 6 & 2 & 1 & $\$ 2,087,085,273$ \\
\hline 1 & 6 & 2 & 2 & $\$ 2,067,678,093$ \\
\hline 1 & 6 & 2 & 3 & $\$ 2,089,448,112$ \\
\hline 1 & 6 & 2 & 4 & $\$ 2,095,606,203$ \\
\hline 1 & 6 & 3 & 1 & $\$ 2,094,067,240$ \\
\hline 1 & 6 & 3 & 2 & $\$ 2,074,660,060$ \\
\hline 1 & 6 & 3 & 3 & $\$ 2,096,430,079$ \\
\hline 1 & 6 & 3 & 4 & $\$ 2,102,588,170$ \\
\hline 1 & 6 & 4 & 1 & $\$ 2,100,409,290$ \\
\hline 1 & 6 & 4 & 2 & $\$ 2,081,002,110$ \\
\hline 1 & 6 & 4 & 3 & $\$ 2,102,772,129$ \\
\hline 1 & 6 & 4 & 4 & $\$ 2,108,930,220$ \\
\hline 1 & 7 & 1 & 1 & $\$ 2,074,083,249$ \\
\hline 1 & 7 & 1 & 2 & $\$ 2,054,676,069$ \\
\hline 1 & 7 & 1 & 3 & $\$ 2,076,446,088$ \\
\hline 1 & 7 & 1 & 4 & $\$ 2,082,604,179$ \\
\hline 1 & 7 & 2 & 1 & $\$ 2,074,059,273$ \\
\hline 1 & 7 & 2 & 2 & $\$ 2,054,652,093$ \\
\hline 1 & 7 & 2 & 3 & $\$ 2,076,422,112$ \\
\hline 1 & 7 & 2 & 4 & $\$ 2,082,580,203$ \\
\hline
\end{tabular}


TABLE B.1 (Cont.)

\begin{tabular}{|c|c|c|c|c|}
\hline $\begin{array}{l}\text { Marketing } \\
\text { Alternative }\end{array}$ & $\begin{array}{c}\text { Glen Canyon } \\
\text { Operational } \\
\text { Scenario } \\
\end{array}$ & $\begin{array}{c}\text { Flaming Gorge } \\
\text { Operational } \\
\text { Scenario } \\
\end{array}$ & $\begin{array}{c}\text { Aspinall } \\
\text { Operational } \\
\text { Scenario }\end{array}$ & $\begin{array}{c}\text { SPASM Estimates } \\
\text { of Wholesale } \\
\text { Power Costs }\end{array}$ \\
\hline 1 & 7 & 3 & 1 & $\$ 2,081,041,240$ \\
\hline 1 & 7 & 3 & 2 & $\$ 2,061,634,060$ \\
\hline 1 & 7 & 3 & 3 & $\$ 2,083,404,079$ \\
\hline 1 & 7 & 3 & 4 & $\$ 2,089,562,170$ \\
\hline 1 & 7 & 4 & 1 & $\$ 2,087,383,290$ \\
\hline 1 & 7 & 4 & 2 & $\$ 2,067,976,110$ \\
\hline 1 & 7 & 4 & 3 & $\$ 2,089,746,129$ \\
\hline 1 & 7 & 4 & 4 & $\$ 2,095,904,220$ \\
\hline 2 & 1 & 1 & 1 & $\$ 2,017,167,905$ \\
\hline 2 & 1 & 1 & 2 & $\$ 1,997,760,725$ \\
\hline 2 & 1 & 1 & 3 & $\$ 2,019,530,744$ \\
\hline 2 & 1 & 1 & 4 & $\$ 2,025,688,835$ \\
\hline 2 & 1 & 2 & 1 & $\$ 2,017,143,929$ \\
\hline 2 & 1 & 2 & 2 & $\$ 1,997,736,749$ \\
\hline 2 & 1 & 2 & 3 & $\$ 2,019,506,768$ \\
\hline 2 & 1 & 2 & 4 & $\$ 2,025,664,859$ \\
\hline 2 & 1 & 3 & 1 & $\$ 2,024,125,896$ \\
\hline 2 & 1 & 3 & 2 & $\$ 2,004,718,716$ \\
\hline 2 & 1 & 3 & 3 & $\$ 2,026,488,735$ \\
\hline 2 & 1 & 3 & 4 & $\$ 2,032,646,826$ \\
\hline 2 & 1 & 4 & 1 & $\$ 2,030,467,946$ \\
\hline 2 & 1 & 4 & 2 & $\$ 2,011,060,766$ \\
\hline 2 & 1 & 4 & 3 & $\$ 2,032,830,785$ \\
\hline 2 & 1 & 4 & 4 & $\$ 2,038,988,876$ \\
\hline 2 & 2 & 1 & 1 & $\$ 2,020,970,236$ \\
\hline 2 & 2 & 1 & 2 & $\$ 2,001,563,056$ \\
\hline 2 & 2 & 1 & 3 & $\$ 2,023,333,075$ \\
\hline 2 & 2 & 1 & 4 & $\$ 2,029,491,166$ \\
\hline 2 & 2 & 2 & 1 & $\$ 2,020,946,260$ \\
\hline 2 & 2 & 2 & 2 & $\$ 2,001,539,080$ \\
\hline 2 & 2 & 2 & 3 & $\$ 2,023,309,099$ \\
\hline 2 & 2 & 2 & 4 & $\$ 2,029,467,190$ \\
\hline
\end{tabular}


TABLE B.1 (Cont.)

\begin{tabular}{|c|c|c|c|c|}
\hline $\begin{array}{l}\text { Marketing } \\
\text { Alternative }\end{array}$ & $\begin{array}{c}\text { Glen Canyon } \\
\text { Operational } \\
\text { Scenario } \\
\end{array}$ & $\begin{array}{c}\text { Flaming Gorge } \\
\text { Operational } \\
\text { Scenario } \\
\end{array}$ & $\begin{array}{l}\text { Aspinall } \\
\text { Operational } \\
\text { Scenario } \\
\end{array}$ & $\begin{array}{c}\text { SPASM Estimates } \\
\text { of Wholesale } \\
\text { Power Costs }\end{array}$ \\
\hline 2 & 2 & 3 & 1 & $\$ 2,027,928,228$ \\
\hline 2 & 2 & 3 & 2 & $\$ 2,008,521,048$ \\
\hline 2 & 2 & 3 & 3 & $\$ 2,030,291,067$ \\
\hline 2 & 2 & 3 & 4 & $\$ 2,036,449,158$ \\
\hline 2 & 2 & 4 & 1 & $\$ 2,034,270,277$ \\
\hline 2 & 2 & 4 & 2 & $\$ 2,014,863,097$ \\
\hline 2 & 2 & 4 & 3 & $\$ 2,036,633,116$ \\
\hline 2 & 2 & 4 & 4 & $\$ 2,042,791,207$ \\
\hline 2 & 3 & 1 & 1 & $\$ 2,076,527,358$ \\
\hline 2 & 3 & 1 & 2 & $\$ 2,057,120,178$ \\
\hline 2 & 3 & 1 & 3 & $\$ 2,078,890,197$ \\
\hline 2 & 3 & 1 & 4 & $\$ 2,085,048,288$ \\
\hline 2 & 3 & 2 & 1 & $\$ 2,076,503,382$ \\
\hline 2 & 3 & 2 & 2 & $\$ 2,057,096,202$ \\
\hline 2 & 3 & 2 & 3 & $\$ 2,078,866,221$ \\
\hline 2 & 3 & 2 & 4 & $\$ 2,085,024,312$ \\
\hline 2 & 3 & 3 & 1 & $\$ 2,083,485,350$ \\
\hline 2 & 3 & 3 & 2 & $\$ 2,064,078,170$ \\
\hline 2 & 3 & 3 & 3 & $\$ 2,085,848,189$ \\
\hline 2 & 3 & 3 & 4 & $\$ 2,092,006,280$ \\
\hline 2 & 3 & 4 & 1 & $\$ 2,089,827,399$ \\
\hline 2 & 3 & 4 & 2 & $\$ 2,070,420,219$ \\
\hline 2 & 3 & 4 & 3 & $\$ 2,092,190,238$ \\
\hline 2 & 3 & 4 & 4 & $\$ 2,098,348,329$ \\
\hline 2 & 4 & 1 & 1 & $\$ 2,080,732,040$ \\
\hline 2 & 4 & 1 & 2 & $\$ 2,061,324,860$ \\
\hline 2 & 4 & 1 & 3 & $\$ 2,083,094,879$ \\
\hline 2 & 4 & 1 & 4 & $\$ 2,089,252,970$ \\
\hline 2 & 4 & 2 & 1 & $\$ 2,080,708,064$ \\
\hline 2 & 4 & 2 & 2 & $\$ 2,061,300,884$ \\
\hline 2 & 4 & 2 & 3 & $\$ 2,083,070,903$ \\
\hline 2 & 4 & 2 & 4 & $\$ 2,089,228,994$ \\
\hline
\end{tabular}


TABLE B.1 (Cont.)

\begin{tabular}{|c|c|c|c|c|}
\hline $\begin{array}{l}\text { Marketing } \\
\text { Alternative }\end{array}$ & $\begin{array}{c}\text { Glen Canyon } \\
\text { Operational } \\
\text { Scenario } \\
\end{array}$ & $\begin{array}{c}\text { Flaming Gorge } \\
\text { Operational } \\
\text { Scenario } \\
\end{array}$ & $\begin{array}{l}\text { Aspinall } \\
\text { Operational } \\
\text { Scenario }\end{array}$ & $\begin{array}{c}\text { SPASM Estimates } \\
\text { of Wholesale } \\
\text { Power Costs }\end{array}$ \\
\hline 2 & 4 & 3 & 1 & $\$ 2,087,690,032$ \\
\hline 2 & 4 & 3 & 2 & $\$ 2,068,282,852$ \\
\hline 2 & 4 & 3 & 3. & $\$ 2,090,052,871$ \\
\hline 2 & 4 & 3 & 4 & $\$ 2,096,210,962$ \\
\hline 2 & 4 & 4 & 1 & $\$ 2,094,032,081$ \\
\hline 2 & 4 & 4 & 2 & $\$ 2,074,624,901$ \\
\hline 2 & 4 & 4 & 3 & $\$ 2,096,394,920$ \\
\hline 2 & 4 & 4 & 4 & $\$ 2,102,553,011$ \\
\hline 2 & 5 & 1 & 1 & $\$ 2,109,190,305$ \\
\hline 2 & 5 & 1 & 2 & $\$ 2,089,783,125$ \\
\hline 2 & 5 & 1 & 3 & $\$ 2,111,553,144$ \\
\hline 2 & 5 & 1 & 4 & $\$ 2,117,711,235$ \\
\hline 2 & 5 & 2 & 1 & $\$ 2,109,166,329$ \\
\hline 2 & 5 & 2 & 2 & $\$ 2,089,759,149$ \\
\hline 2 & 5 & 2 & 3 & $\$ 2,111,529,168$ \\
\hline 2 & 5 & 2 & 4 & $\$ 2,117,687,259$ \\
\hline 2 & 5 & 3 & 1 & $\$ 2,116,148,296$ \\
\hline 2 & 5 & 3 & 2 & $\$ 2,096,741,116$ \\
\hline 2 & 5 & 3 & 3 & $\$ 2,118,511,135$ \\
\hline 2 & 5 & 3 & 4 & $\$ 2,124,669,226$ \\
\hline 2 & 5 & 4 & 1 & $\$ 2,122,490,346$ \\
\hline 2 & 5 & 4 & 2 & $\$ 2,103,083,166$ \\
\hline 2 & 5 & 4 & 3 & $\$ 2,124,853,185$ \\
\hline 2 & 5 & 4 & 4 & $\$ 2,131,011,276$ \\
\hline 2 & 6 & 1 & 1 & $\$ 2,138,206,305$ \\
\hline 2 & 6 & 1 & 2 & $\$ 2,118,799,125$ \\
\hline 2 & 6 & 1 & 3 & $\$ 2,140,569,144$ \\
\hline 2 & 6 & 1 & 4 & $\$ 2,146,727,235$ \\
\hline 2 & 6 & 2 & 1 & $\$ 2,138,182,329$ \\
\hline 2 & 6 & 2 & 2 & $\$ 2,118,775,149$ \\
\hline 2 & 6 & 2 & 3 & $\$ 2,140,545,168$ \\
\hline 2 & 6 & 2 & 4 & $\$ 2,146,703,259$ \\
\hline
\end{tabular}


TABLE B.1 (Cont.)

\begin{tabular}{|c|c|c|c|c|}
\hline $\begin{array}{l}\text { Marketing } \\
\text { Alternative }\end{array}$ & $\begin{array}{c}\text { Glen Canyon } \\
\text { Operational } \\
\text { Scenario } \\
\end{array}$ & $\begin{array}{c}\text { Flaming Gorge } \\
\text { Operational } \\
\text { Scenario } \\
\end{array}$ & $\begin{array}{c}\text { Aspinall } \\
\text { Operational } \\
\text { Scenario } \\
\end{array}$ & $\begin{array}{c}\text { SPASM Estimates } \\
\text { of Wholesale } \\
\text { Power Costs }\end{array}$ \\
\hline 2 & 6 & 3 & 1 & $\$ 2,145,164,296$ \\
\hline 2 & 6 & 3 & 2 & $\$ 2,125,757,116$ \\
\hline 2 & 6 & 3 & 3 & $\$ 2,147,527,135$ \\
\hline 2 & 6 & 3 & 4 & $\$ 2,153,685,226$ \\
\hline 2 & 6 & 4 & 1 & $\$ 2,151,506,346$ \\
\hline 2 & 6 & 4 & 2 & $\$ 2,132,099,166$ \\
\hline 2 & 6 & 4 & 3 & $\$ 2,153,869,185$ \\
\hline 2 & 6 & 4 & 4 & $\$ 2,160,027,276$ \\
\hline 2 & 7 & 1 & 1 & $\$ 2,125,180,305$ \\
\hline 2 & 7 & 1 & 2 & $\$ 2,105,773,125$ \\
\hline 2 & 7 & 1 & 3 & $\$ 2,127,543,144$ \\
\hline 2 & 7 & 1 & 4 & $\$ 2,133,701,235$ \\
\hline 2 & 7 & 2 & 1 & $\$ 2,125,156,329$ \\
\hline 2 & 7 & 2 & 2 & $\$ 2,105,749,149$ \\
\hline 2 & 7 & 2 & 3 & $\$ 2,127,519,168$ \\
\hline 2 & 7 & 2 & 4 & $\$ 2,133,677,259$ \\
\hline 2 & 7 & 3 & 1 & $\$ 2,132,138,296$ \\
\hline 2 & 7 & 3 & 2 & $\$ 2,112,731,116$ \\
\hline 2 & 7 & 3 & 3 & $\$ 2,134,501,135$ \\
\hline 2 & 7 & 3 & 4 & $\$ 2,140,659,226$ \\
\hline 2 & 7 & 4 & 1 & $\$ 2,138,480,346$ \\
\hline 2 & 7 & 4 & 2 & $\$ 2,119,073,166$ \\
\hline 2 & 7 & 4 & 3 & $\$ 2,140,843,185$ \\
\hline 2 & 7 & 4 & 4 & $\$ 2,147,001,276$ \\
\hline 3 & 1 & 1 & 1 & $\$ 2,009,357,365$ \\
\hline 3 & 1 & 1 & 2 & $\$ 1,999,446,751$ \\
\hline 3 & 1 & 1 & 3 & $\$ 2,011,720,204$ \\
\hline 3 & 1 & 1 & 4 & $\$ 2,017,878,295$ \\
\hline 3 & 1 & 2 & 1 & $\$ 2,009,333,389$ \\
\hline 3 & 1 & 2 & 2 & $\$ 1,999,422,775$ \\
\hline 3 & 1 & 2 & 3 & $\$ 2,011,696,228$ \\
\hline 3 & 1 & 2 & 4 & $\$ 2,017,854,319$ \\
\hline
\end{tabular}


TABLE B.1 (Cont.)

\begin{tabular}{|c|c|c|c|c|}
\hline $\begin{array}{l}\text { Marketing } \\
\text { Alternative }\end{array}$ & $\begin{array}{c}\text { Glen Canyon } \\
\text { Operational } \\
\text { Scenario } \\
\end{array}$ & $\begin{array}{c}\text { Flaming Gorge } \\
\text { Operational } \\
\text { Scenario } \\
\end{array}$ & $\begin{array}{c}\text { Aspinall } \\
\text { Operational } \\
\text { Scenario } \\
\end{array}$ & $\begin{array}{c}\text { SPASM Estimates } \\
\text { of Wholesale } \\
\text { Power Costs }\end{array}$ \\
\hline 3 & 1 & 3 & 1 & $\$ 2,016,315,356$ \\
\hline 3 & 1 & 3 & 2 & $\$ 2,002,969,388$ \\
\hline 3 & 1 & 3 & 3 & $\$ 2,018,678,195$ \\
\hline 3 & 1 & 3 & 4 & $\$ 2,024,836,286$ \\
\hline 3 & 1 & 4 & 1 & $\$ 2,022,657,406$ \\
\hline 3 & 1 & 4 & 2 & $\$ 2,006,187,992$ \\
\hline 3 & 1 & 4 & 3 & $\$ 2,025,020,245$ \\
\hline 3 & 1 & 4 & 4 & $\$ 2,031,178,336$ \\
\hline 3 & 2 & 1 & 1 & $\$ 2,013,159,696$ \\
\hline 3 & 2 & 1 & 2 & $\$ 2,001,400,123$ \\
\hline 3 & 2 & 1 & 3 & $\$ 2,015,522,535$ \\
\hline 3 & 2 & 1 & 4 & $\$ 2,021,680,626$ \\
\hline 3 & 2 & 2 & 1 & $\$ 2,013,135,720$ \\
\hline 3 & 2 & 2 & 2 & $\$ 2,001,376,147$ \\
\hline 3 & 2 & 2 & 3 & $\$ 2,015,498,559$ \\
\hline 3 & 2 & 2 & 4 & $\$ 2,021,656,650$ \\
\hline 3 & 2 & 3 & 1 & $\$ 2,020,117,688$ \\
\hline 3 & 2 & 3 & 2 & $\$ 2,004,922,759$ \\
\hline 3 & 2 & 3 & 3 & $\$ 2,022,480,527$ \\
\hline 3 & 2 & 3 & 4 & $\$ 2,028,638,618$ \\
\hline 3 & 2 & 4 & 1 & $\$ 2,026,459,737$ \\
\hline 3 & 2 & 4 & 2 & $\$ 2,008,141,364$ \\
\hline 3 & 2 & 4 & 3 & $\$ 2,028,822,576$ \\
\hline 3 & 2 & 4 & 4 & $\$ 2,034,980,667$ \\
\hline 3 & 3 & 1 & 1 & $\$ 2,068,716,818$ \\
\hline 3 & 3 & 1 & 2 & $\$ 2,049,309,638$ \\
\hline 3 & 3 & 1 & 3 & $\$ 2,071,079,657$ \\
\hline 3 & 3 & 1 & 4 & $\$ 2,077,237,748$ \\
\hline 3 & 3 & 2 & 1 & $\$ 2,068,692,842$ \\
\hline 3 & 3 & 2 & 2 & $\$ 2,049,285,662$ \\
\hline 3 & 3 & 2 & 3 & $\$ 2,071,055,681$ \\
\hline 3 & 3 & 2 & 4 & $\$ 2,077,213,772$ \\
\hline
\end{tabular}


TABLE B.1 (Cont.)

\begin{tabular}{|c|c|c|c|c|}
\hline $\begin{array}{l}\text { Marketing } \\
\text { Alternative }\end{array}$ & $\begin{array}{c}\text { Glen Canyon } \\
\text { Operational } \\
\text { Scenario } \\
\end{array}$ & $\begin{array}{c}\text { Flaming Gorge } \\
\text { Operational } \\
\text { Scenario } \\
\end{array}$ & $\begin{array}{c}\text { Aspinall } \\
\text { Operational } \\
\text { Scenario } \\
\end{array}$ & $\begin{array}{c}\text { SPASM Estimates } \\
\text { of Wholesale } \\
\text { Power Costs }\end{array}$ \\
\hline 3 & 3 & 3 & 1 & $\$ 2,075,674,810$ \\
\hline 3 & 3 & 3 & 2 & $\$ 2,056,267,630$ \\
\hline 3 & 3 & 3 & 3 & $\$ 2,078,037,649$ \\
\hline 3 & 3 & 3 & 4 & $\$ 2,084,195,740$ \\
\hline 3 & 3 & 4 & 1 & $\$ 2,082,016,859$ \\
\hline 3 & 3 & 4 & 2 & $\$ 2,062,609,679$ \\
\hline 3 & 3 & 4 & 3 & $\$ 2,084,379,698$ \\
\hline 3 & 3 & 4 & 4 & $\$ 2,090,537,789$ \\
\hline 3 & 4 & 1 & 1 & $\$ 2,072,921,500$ \\
\hline 3 & 4 & 1 & 2 & $\$ 2,053,514,320$ \\
\hline 3 & 4 & 1 & 3 & $\$ 2,075,284,339$ \\
\hline 3 & 4 & 1 & 4 & $\$ 2,081,442,430$ \\
\hline 3 & 4 & 2 & 1 & $\$ 2,072,897,524$ \\
\hline 3 & 4 & 2 & 2 & $\$ 2,053,490,344$ \\
\hline 3 & 4 & 2 & 3 & $\$ 2,075,260,363$ \\
\hline 3 & 4 & 2 & 4 & $\$ 2,081,418,454$ \\
\hline 3 & 4 & 3 & 1 & $\$ 2,079,879,492$ \\
\hline 3 & 4 & 3 & 2 & $\$ 2,060,472,312$ \\
\hline 3 & 4 & 3 & 3 & $\$ 2,082,242,331$ \\
\hline 3 & 4 & 3 & 4 & $\$ 2,088,400,422$ \\
\hline 3 & 4 & 4 & 1 & $\$ 2,086,221,541$ \\
\hline 3 & 4 & 4 & 2 & $\$ 2,066,814,361$ \\
\hline 3 & 4 & 4 & 3 & $\$ 2,088,584,380$ \\
\hline 3 & 4 & 4 & 4 & $\$ 2,094,742,471$ \\
\hline 3 & 5 & 1 & 1 & $\$ 2,101,379,765$ \\
\hline 3 & 5 & 1 & 2 & $\$ 2,081,972,585$ \\
\hline 3 & 5 & 1 & 3 & $\$ 2,103,742,604$ \\
\hline 3 & 5 & 1 & 4 & $\$ 2,109,900,695$ \\
\hline 3 & 5 & 2 & 1 & $\$ 2,101,355,789$ \\
\hline 3 & 5 & 2 & 2 & $\$ 2,081,948,609$ \\
\hline 3 & 5 & 2 & 3 & $\$ 2,103,718,628$ \\
\hline 3 & 5 & 2 & 4 & $\$ 2,109,876,719$ \\
\hline
\end{tabular}


TABLE B.1 (Cont.)

\begin{tabular}{|c|c|c|c|c|}
\hline $\begin{array}{l}\text { Marketing } \\
\text { Alternative }\end{array}$ & $\begin{array}{c}\text { Glen Canyon } \\
\text { Operational } \\
\text { Scenario } \\
\end{array}$ & $\begin{array}{c}\text { Flaming Gorge } \\
\text { Operational } \\
\text { Scenario } \\
\end{array}$ & $\begin{array}{l}\text { Aspinall } \\
\text { Operational } \\
\text { Scenario } \\
\end{array}$ & $\begin{array}{c}\text { SPASM Estimates } \\
\text { of Wholesale } \\
\text { Power Costs }\end{array}$ \\
\hline 3 & 5 & 3 & 1 & $\$ 2,108,337,756$ \\
\hline 3 & 5 & 3 & 2 & $\$ 2,088,930,576$ \\
\hline 3 & 5 & 3 & 3 & $\$ 2,110,700,595$ \\
\hline 3 & 5 & 3 & 4 & $\$ 2,116,858,686$ \\
\hline 3 & 5 & 4 & 1 & $\$ 2,114,679,806$ \\
\hline 3 & 5 & 4 & 2 & $\$ 2,095,272,626$ \\
\hline 3 & 5 & 4 & 3 & $\$ 2,117,042,645$ \\
\hline 3 & 5 & 4 & 4 & $\$ 2,123,200,736$ \\
\hline 3 & 6 & 1 & 1 & $\$ 2,130,395,765$ \\
\hline 3 & 6 & 1 & 2 & $\$ 2,110,988,585$ \\
\hline 3 & 6 & 1 & 3 & $\$ 2,132,758,604$ \\
\hline 3 & 6 & 1 & 4 & $\$ 2,138,916,695$ \\
\hline 3 & 6 & 2 & 1 & $\$ 2,130,371,789$ \\
\hline 3 & 6 & 2 & 2 & $\$ 2,110,964,609$ \\
\hline 3 & 6 & 2 & 3 & $\$ 2,132,734,628$ \\
\hline 3 & 6 & 2 & 4 & $\$ 2,138,892,719$ \\
\hline 3 & 6 & 3 & 1 & $\$ 2,137,353,756$ \\
\hline 3 & 6 & 3 & 2 & $\$ 2,117,946,576$ \\
\hline 3 & 6 & 3 & 3 & $\$ 2,139,716,595$ \\
\hline 3 & 6 & 3 & 4 & $\$ 2,145,874,686$ \\
\hline 3 & 6 & 4 & 1 & $\$ 2,143,695,806$ \\
\hline 3 & 6 & 4 & 2 & $\$ 2,124,288,626$ \\
\hline 3 & 6 & 4 & 3 & $\$ 2,146,058,645$ \\
\hline 3 & 6 & 4 & 4 & $\$ 2,152,216,736$ \\
\hline 3 & 7 & 1 & 1 & $\$ 2,117,369,765$ \\
\hline 3 & 7 & 1 & 2 & $\$ 2,097,962,585$ \\
\hline 3 & 7 & 1 & 3 & $\$ 2,119,732,604$ \\
\hline 3 & 7 & 1 & 4 & $\$ 2,125,890,695$ \\
\hline 3 & 7 & 2 & 1 & $\$ 2,117,345,789$ \\
\hline 3 & 7 & 2 & 2 & $\$ 2,097,938,609$ \\
\hline 3 & 7 & 2 & 3 & $\$ 2,119,708,628$ \\
\hline 3 & 7 & 2 & 4 & $\$ 2,125,866,719$ \\
\hline
\end{tabular}


TABLE B.1 (Cont.)

\begin{tabular}{|c|c|c|c|c|}
\hline $\begin{array}{l}\text { Marketing } \\
\text { Alternative }\end{array}$ & $\begin{array}{c}\text { Glen Canyon } \\
\text { Operational } \\
\text { Scenario } \\
\end{array}$ & $\begin{array}{c}\text { Flaming Gorge } \\
\text { Operational } \\
\text { Scenario } \\
\end{array}$ & $\begin{array}{c}\text { Aspinall } \\
\text { Operational } \\
\text { Scenario } \\
\end{array}$ & $\begin{array}{c}\text { SPASM Estimates } \\
\text { of Wholesale } \\
\text { Power Costs } \\
\end{array}$ \\
\hline 3 & 7 & 3 & 1 & $\$ 2,124,327,756$ \\
\hline 3 & 7 & 3 & 2 & $\$ 2,104,920,576$ \\
\hline 3 & 7 & 3 & 3 & $\$ 2,126,690,595$ \\
\hline 3 & 7 & 3 & 4 & $\$ 2,132,848,686$ \\
\hline 3 & 7 & 4 & 1 & $\$ 2,130,669,806$ \\
\hline 3 & 7 & 4 & 2 & $\$ 2,111,262,626$ \\
\hline 3 & 7 & 4 & 3 & $\$ 2,133,032,645$ \\
\hline 3 & 7 & 4 & 4 & $\$ 2,139,190,736$ \\
\hline 4 & 1 & 1 & 1 & $\$ 2,087,947,606$ \\
\hline 4 & 1 & 1 & 2 & $\$ 2,078,124,587$ \\
\hline 4 & 1 & 1 & 3 & $\$ 2,089,169,714$ \\
\hline 4 & 1 & 1 & 4 & $\$ 2,092,296,358$ \\
\hline 4 & 1 & 2 & 1 & $\$ 2,087,923,630$ \\
\hline 4 & 1 & 2 & 2 & $\$ 2,078,100,611$ \\
\hline 4 & 1 & 2 & 3 & $\$ 2,089,145,738$ \\
\hline 4 & 1 & 2 & 4 & $\$ 2,092,272,382$ \\
\hline 4 & 1 & 3 & 1 & $\$ 2,091,470,243$ \\
\hline 4 & 1 & 3 & 2 & $\$ 2,081,647,224$ \\
\hline 4 & 1 & 3 & 3 & $\$ 2,092,692,350$ \\
\hline 4 & 1 & 3 & 4 & $\$ 2,095,818,994$ \\
\hline 4 & 1 & 4 & 1 & $\$ 2,094,688,847$ \\
\hline 4 & 1 & 4 & 2 & $\$ 2,084,865,828$ \\
\hline 4 & 1 & 4 & 3 & $\$ 2,095,910,954$ \\
\hline 4 & 1 & 4 & 4 & $\$ 2,099,037,598$ \\
\hline 4 & 2 & 1 & 1 & $\$ 2,089,900,978$ \\
\hline 4 & 2 & 1 & 2 & $\$ 2,080,077,959$ \\
\hline 4 & 2 & 1 & 3 & $\$ 2,091,123,086$ \\
\hline 4 & 2 & 1 & 4 & $\$ 2,094,249,730$ \\
\hline 4 & 2 & 2 & 1 & $\$ 2,089,877,002$ \\
\hline 4 & 2 & 2 & 2 & $\$ 2,080,053,983$ \\
\hline 4 & 2 & 2 & 3 & $\$ 2,091,099,110$ \\
\hline 4 & 2 & 2 & 4 & $\$ 2,094,225,754$ \\
\hline
\end{tabular}


TABLE B.1 (Cont.)

\begin{tabular}{|c|c|c|c|c|}
\hline $\begin{array}{l}\text { Marketing } \\
\text { Alternative }\end{array}$ & $\begin{array}{c}\text { Glen Canyon } \\
\text { Operational } \\
\text { Scenario } \\
\end{array}$ & $\begin{array}{c}\text { Flaming Gorge } \\
\text { Operational } \\
\text { Scenario } \\
\end{array}$ & $\begin{array}{c}\text { Aspinall } \\
\text { Operational } \\
\text { Scenario } \\
\end{array}$ & $\begin{array}{c}\text { SPASM Estimates } \\
\text { of Wholesale } \\
\text { Power Costs }\end{array}$ \\
\hline 4 & 2 & 3 & 1 & $\$ 2,093,423,614$ \\
\hline 4 & 2 & 3 & 2 & $\$ 2,083,600,595$ \\
\hline 4 & 2 & 3 & 3 & $\$ 2,094,645,722$ \\
\hline 4 & 2 & 3 & $4^{\circ}$ & $\$ 2,097,772,366$ \\
\hline 4 & 2 & 4 & 1 & $\$ 2,096,642,218$ \\
\hline 4 & 2 & 4 & 2 & $\$ 2,086,819,200$ \\
\hline 4 & 2 & 4 & 3 & $\$ 2,097,864,326$ \\
\hline 4 & 2 & 4 & 4 & $\$ 2,100,990,970$ \\
\hline 4 & 3 & 1 & 1 & $\$ 2,118,070,380$ \\
\hline 4 & 3 & 1 & 2 & $\$ 2,108,247,361$ \\
\hline 4 & 3 & 1 & 3 & $\$ 2,119,292,487$ \\
\hline 4 & 3 & 1 & 4 & $\$ 2,122,419,131$ \\
\hline 4 & 3 & 2 & 1 & $\$ 2,118,046,404$ \\
\hline 4 & 3 & 2 & 2 & $\$ 2,108,223,385$ \\
\hline 4 & 3 & 2 & 3 & $\$ 2,119,268,511$ \\
\hline 4 & 3 & 2 & 4 & $\$ 2,122,395,155$ \\
\hline 4 & 3 & 3 & 1 & $\$ 2,121,593,016$ \\
\hline 4 & 3 & 3 & 2 & $\$ 2,111,769,997$ \\
\hline 4 & 3 & 3 & 3 & $\$ 2,122,815,124$ \\
\hline 4 & 3 & 3 & 4 & $\$ 2,125,941,768$ \\
\hline 4 & 3 & 4 & 1 & $\$ 2,124,811,620$ \\
\hline 4 & 3 & 4 & 2 & $\$ 2,114,988,601$ \\
\hline 4 & 3 & 4 & 3 & $\$ 2,126,033,728$ \\
\hline 4 & 3 & 4 & 4 & $\$ 2,129,160,372$ \\
\hline 4 & 4 & 1 & 1 & $\$ 2,120,272,022$ \\
\hline 4 & 4 & 1 & 2 & $\$ 2,110,449,003$ \\
\hline 4 & 4 & 1 & 3 & $\$ 2,121,494,130$ \\
\hline 4 & 4 & 1 & 4 & $\$ 2,124,620,774$ \\
\hline 4 & 4 & 2 & 1 & $\$ 2,120,248,046$ \\
\hline 4 & 4 & 2 & 2 & $\$ 2,110,425,027$ \\
\hline 4 & 4 & 2 & 3 & $\$ 2,121,470,154$ \\
\hline 4 & 4 & 2 & 4 & $\$ 2,124,596,798$ \\
\hline
\end{tabular}


TABLE B.1 (Cont.)

\begin{tabular}{|c|c|c|c|c|}
\hline $\begin{array}{l}\text { Marketing } \\
\text { Alternative }\end{array}$ & $\begin{array}{c}\text { Glen Canyon } \\
\text { Operational } \\
\text { Scenario } \\
\end{array}$ & $\begin{array}{c}\text { Flaming Gorge } \\
\text { Operational } \\
\text { Scenario } \\
\end{array}$ & $\begin{array}{c}\text { Aspinall } \\
\text { Operational } \\
\text { Scenario } \\
\end{array}$ & $\begin{array}{c}\text { SPASM Estimates } \\
\text { of Wholesale } \\
\text { Power Costs }\end{array}$ \\
\hline 4 & 4 & 3 & 1 & $\$ 2,123,794,658$ \\
\hline 4 & 4 & 3 & 2 & $\$ 2,113,971,640$ \\
\hline 4 & 4 & 3 & 3 & $\$ 2,125,016,766$ \\
\hline 4 & 4 & 3 & 4 & $\$ 2,128,143,410$ \\
\hline 4 & 4 & 4 & 1 & $\$ 2,127,013,263$ \\
\hline 4 & 4 & 4 & 2 & $\$ 2,117,190,244$ \\
\hline 4 & 4 & 4 & 3 & $\$ 2,128,235,370$ \\
\hline 4 & 4 & 4 & 4 & $\$ 2,131,362,014$ \\
\hline 4 & 5 & 1 & 1 & $\$ 2,134,786,046$ \\
\hline 4 & 5 & 1 & 2 & $\$ 2,124,963,027$ \\
\hline 4 & 5 & 1 & 3 & $\$ 2,136,008,154$ \\
\hline 4 & 5 & 1 & 4 & $\$ 2,139,134,798$ \\
\hline 4 & 5 & 2 & 1 & $\$ 2,134,762,070$ \\
\hline 4 & 5 & 2 & 2 & $\$ 2,124,939,051$ \\
\hline 4 & 5 & 2 & 3 & $\$ 2,135,984,178$ \\
\hline 4 & 5 & 2 & 4 & $\$ 2,139,110,822$ \\
\hline 4 & 5 & 3 & 1 & $\$ 2,138,308,683$ \\
\hline 4 & 5 & 3 & 2 & $\$ 2,128,485,664$ \\
\hline 4 & 5 & 3 & 3 & $\$ 2,139,530,790$ \\
\hline 4 & 5 & 3 & 4 & $\$ 2,143,534,522$ \\
\hline 4 & 5 & 4 & 1 & $\$ 2,141,527,287$ \\
\hline 4 & 5 & 4 & 2 & $\$ 2,131,704,268$ \\
\hline 4 & 5 & 4 & 3 & $\$ 2,143,718,481$ \\
\hline 4 & 5 & 4 & 4 & $\$ 2,149,876,572$ \\
\hline 4 & 6 & 1 & 1 & $\$ 2,157,071,601$ \\
\hline 4 & 6 & 1 & 2 & $\$ 2,139,649,587$ \\
\hline 4 & 6 & 1 & 3 & $\$ 2,159,434,440$ \\
\hline 4 & 6 & 1 & 4 & $\$ 2,165,592,531$ \\
\hline 4 & 6 & 2 & 1 & $\$ 2,157,047,625$ \\
\hline 4 & 6 & 2 & 2 & $\$ 2,139,625,611$ \\
\hline 4 & 6 & 2 & 3 & $\$ 2,159,410,464$ \\
\hline 4 & 6 & 2 & 4 & $\$ 2,165,568,555$ \\
\hline
\end{tabular}


TABLE B.1 (Cont.)

\begin{tabular}{|c|c|c|c|c|}
\hline $\begin{array}{l}\text { Marketing } \\
\text { Alternative }\end{array}$ & $\begin{array}{c}\text { Glen Canyon } \\
\text { Operational } \\
\text { Scenario } \\
\end{array}$ & $\begin{array}{c}\text { Flaming Gorge } \\
\text { Operational } \\
\text { Scenario } \\
\end{array}$ & $\begin{array}{l}\text { Aspinall } \\
\text { Operational } \\
\text { Scenario } \\
\end{array}$ & $\begin{array}{c}\text { SPASM Estimates } \\
\text { of Wholesale } \\
\text { Power Costs }\end{array}$ \\
\hline 4 & 6 & 3 & 1 & $\$ 2,164,029,592$ \\
\hline 4 & 6 & 3 & 2 & $\$ 2,144,622,412$ \\
\hline 4 & 6 & 3 & 3 & $\$ 2,166,392,431$ \\
\hline 4 & 6 & 3 & 4 & $\$ 2,172,550,522$ \\
\hline 4 & 6 & 4 & 1 & $\$ 2,170,371,642$ \\
\hline 4 & 6 & 4 & 2 & $\$ 2,150,964,462$ \\
\hline 4 & 6 & 4 & 3 & $\$ 2,172,734,481$ \\
\hline 4 & 6 & 4 & 4 & $\$ 2,178,892,572$ \\
\hline 4 & 7 & 1 & 1 & $\$ 2,144,045,601$ \\
\hline 4 & 7 & 1 & 2 & $\$ 2,133,056,427$ \\
\hline 4 & 7 & 1 & 3 & $\$ 2,146,408,440$ \\
\hline 4 & 7 & 1 & 4 & $\$ 2,152,566,531$ \\
\hline 4 & 7 & 2 & 1 & $\$ 2,144,021,625$ \\
\hline 4 & 7 & 2 & 2 & $\$ 2,133,032,451$ \\
\hline 4 & 7 & 2 & 3 & $\$ 2,146,384,464$ \\
\hline 4 & 7 & 2 & 4 & $\$ 2,152,542,555$ \\
\hline 4 & 7 & 3 & 1 & $\$ 2,151,003,592$ \\
\hline 4 & 7 & 3 & 2 & $\$ 2,136,579,064$ \\
\hline 4 & 7 & 3 & 3 & $\$ 2,153,366,431$ \\
\hline 4 & 7 & 3 & 4 & $\$ 2,159,524,522$ \\
\hline 4 & 7 & 4 & 1 & $\$ 2,157,345,642$ \\
\hline 4 & 7 & 4 & 2 & $\$ 2,139,797,668$ \\
\hline 4 & 7 & 4 & 3 & $\$ 2,159,708,481$ \\
\hline 4 & 7 & 4 & 4 & $\$ 2,165,866,572$ \\
\hline 5 & 1 & 1 & 1 & $\$ 2,041,682,636$ \\
\hline 5 & 1 & 1 & 2 & $\$ 2,031,859,617$ \\
\hline 5 & 1 & 1 & 3 & $\$ 2,042,904,744$ \\
\hline 5 & 1 & 1 & 4 & $\$ 2,046,031,388$ \\
\hline 5 & 1 & 2 & 1 & $\$ 2,041,658,660$ \\
\hline 5 & 1 & 2 & 2 & $\$ 2,031,835,641$ \\
\hline 5 & 1 & 2 & 3 & $\$ 2,042,880,768$ \\
\hline 5 & 1 & 2 & 4 & $\$ 2,046,007,412$ \\
\hline
\end{tabular}


TABLE B.1 (Cont.)

\begin{tabular}{|c|c|c|c|c|}
\hline $\begin{array}{l}\text { Marketing } \\
\text { Alternative }\end{array}$ & $\begin{array}{c}\text { Glen Canyon } \\
\text { Operational } \\
\text { Scenario } \\
\end{array}$ & $\begin{array}{c}\text { Flaming Gorge } \\
\text { Operational } \\
\text { Scenario } \\
\end{array}$ & $\begin{array}{l}\text { Aspinall } \\
\text { Operational } \\
\text { Scenario } \\
\end{array}$ & $\begin{array}{c}\text { SPASM Estimates } \\
\text { of Wholesale } \\
\text { Power Costs }\end{array}$ \\
\hline 5 & 1 & 3 & 1 & $\$ 2,045,205,273$ \\
\hline 5 & 1 & 3 & 2 & $\$ 2,035,382,254$ \\
\hline 5 & 1 & 3 & 3 & $\$ 2,046,427,380$ \\
\hline 5 & 1 & 3 & 4 & $\$ 2,049,554,024$ \\
\hline 5 & 1 & 4 & 1 & $\$ 2,048,423,877$ \\
\hline 5 & 1 & 4 & 2 & $\$ 2,038,600,858$ \\
\hline 5 & 1 & 4 & 3 & $\$ 2,049,645,984$ \\
\hline 5 & 1 & 4 & 4 & $\$ 2,052,772,628$ \\
\hline 5 & 2 & 1 & 1 & $\$ 2,043,636,008$ \\
\hline 5 & 2 & 1 & 2 & $\$ 2,033,812,989$ \\
\hline 5 & 2 & 1 & 3 & $\$ 2,044,858,116$ \\
\hline 5 & 2 & 1 & 4 & $\$ 2,047,984,760$ \\
\hline 5 & 2 & 2 & 1 & $\$ 2,043,612,032$ \\
\hline 5 & 2 & 2 & 2 & $\$ 2,033,789,013$ \\
\hline 5 & 2 & 2 & 3 & $\$ 2,044,834,140$ \\
\hline 5 & 2 & 2 & 4 & $\$ 2,047,960,784$ \\
\hline 5 & 2 & 3 & 1 & $\$ 2,047,158,644$ \\
\hline 5 & 2 & 3 & 2 & $\$ 2,037,335,625$ \\
\hline 5 & 2 & 3 & 3 & $\$ 2,048,380,752$ \\
\hline 5 & 2 & 3 & 4 & $\$ 2,051,507,396$ \\
\hline 5 & 2 & 4 & 1 & $\$ 2,050,377,248$ \\
\hline 5 & 2 & 4 & 2 & $\$ 2,040,554,230$ \\
\hline 5 & 2 & 4 & 3 & $\$ 2,051,599,356$ \\
\hline 5 & 2 & 4 & 4 & $\$ 2,054,726,000$ \\
\hline 5 & 3 & 1 & 1 & $\$ 2,071,805,410$ \\
\hline 5 & 3 & 1 & 2 & $\$ 2,061,982,391$ \\
\hline 5 & 3 & 1 & 3 & $\$ 2,073,027,517$ \\
\hline 5 & 3 & 1 & 4 & $\$ 2,076,154,161$ \\
\hline 5 & 3 & 2 & 1 & $\$ 2,071,781,434$ \\
\hline 5 & 3 & 2 & 2 & $\$ 2,061,958,415$ \\
\hline 5 & 3 & 2 & 3 & $\$ 2,073,003,541$ \\
\hline 5 & 3 & 2 & 4 & $\$ 2,076,130,185$ \\
\hline
\end{tabular}


TABLE B.1 (Cont.)

\begin{tabular}{|c|c|c|c|c|}
\hline $\begin{array}{l}\text { Marketing } \\
\text { Alternative }\end{array}$ & $\begin{array}{c}\text { Glen Canyon } \\
\text { Operational } \\
\text { Scenario } \\
\end{array}$ & $\begin{array}{c}\text { Flaming Gorge } \\
\text { Operational } \\
\text { Scenario } \\
\end{array}$ & $\begin{array}{c}\text { Aspinall } \\
\text { Operational } \\
\text { Scenario } \\
\end{array}$ & $\begin{array}{c}\text { SPASM Estimates } \\
\text { of Wholesale } \\
\text { Power Costs } \\
\end{array}$ \\
\hline 5 & 3 & 3 & 1 & $\$ 2,075,328,046$ \\
\hline 5 & 3 & 3 & 2 & $\$ 2,065,505,027$ \\
\hline 5 & 3 & 3 & 3 & $\$ 2,076,550,154$ \\
\hline 5 & 3 & 3 & 4 & $\$ 2,079,676,798$ \\
\hline 5 & 3 & 4 & 1 & $\$ 2,078,546,650$ \\
\hline 5 & 3 & 4 & 2 & $\$ 2,068,723,631$ \\
\hline 5 & 3 & 4 & 3 & $\$ 2,079,768,758$ \\
\hline 5 & 3 & 4 & 4 & $\$ 2,082,895,402$ \\
\hline 5 & 4 & 1 & 1 & $\$ 2,074,007,052$ \\
\hline 5 & 4 & 1 & 2 & $\$ 2,064,184,033$ \\
\hline 5 & 4 & 1 & 3 & $\$ 2,075,229,160$ \\
\hline 5 & 4 & 1 & 4 & $\$ 2,078,355,804$ \\
\hline 5 & 4 & 2 & 1 & $\$ 2,073,983,076$ \\
\hline 5 & 4 & 2 & 2 & $\$ 2,064,160,057$ \\
\hline 5 & 4 & 2 & 3 & $\$ 2,075,205,184$ \\
\hline 5 & 4 & 2 & 4 & $\$ 2,078,331,828$ \\
\hline 5 & 4 & 3 & 1 & $\$ 2,077,529,688$ \\
\hline 5 & 4 & 3 & 2 & $\$ 2,067,706,670$ \\
\hline 5 & 4 & 3 & 3 & $\$ 2,078,751,796$ \\
\hline 5 & 4 & 3 & 4 & $\$ 2,081,878,440$ \\
\hline 5 & 4 & 4 & 1 & $\$ 2,080,748,293$ \\
\hline 5 & 4 & 4 & 2 & $\$ 2,070,925,274$ \\
\hline 5 & 4 & 4 & 3 & $\$ 2,081,970,400$ \\
\hline 5 & 4 & 4 & 4 & $\$ 2,085,097,044$ \\
\hline 5 & 5 & 1 & 1 & $\$ 2,088,521,076$ \\
\hline 5 & 5 & 1 & 2 & $\$ 2,078,698,057$ \\
\hline 5 & 5 & 1 & 3 & $\$ 2,089,931,470$ \\
\hline 5 & 5 & 1 & 4 & $\$ 2,096,089,561$ \\
\hline 5 & 5 & 2 & 1 & $\$ 2,088,497,100$ \\
\hline 5 & 5 & 2 & 2 & $\$ 2,078,674,081$ \\
\hline 5 & 5 & 2 & 3 & $\$ 2,089,907,494$ \\
\hline 5 & 5 & 2 & 4 & $\$ 2,096,065,585$ \\
\hline
\end{tabular}


TABLE B.1 (Cont.)

\begin{tabular}{|c|c|c|c|c|}
\hline $\begin{array}{l}\text { Marketing } \\
\text { Alternative }\end{array}$ & $\begin{array}{c}\text { Glen Canyon } \\
\text { Operational } \\
\text { Scenario }\end{array}$ & $\begin{array}{c}\text { Flaming Gorge } \\
\text { Operational } \\
\text { Scenario }\end{array}$ & $\begin{array}{l}\text { Aspinall } \\
\text { Operational } \\
\text { Scenario }\end{array}$ & $\begin{array}{c}\text { SPASM Estimates } \\
\text { of Wholesale } \\
\text { Power Costs }\end{array}$ \\
\hline 5 & 5 & 3 & 1 & $\$ 2,094,526,622$ \\
\hline 5 & 5 & 3 & 2 & $\$ 2,082,220,694$ \\
\hline 5 & 5 & 3 & 3 & $\$ 2,096,889,461$ \\
\hline 5 & 5 & 3 & 4 & $\$ 2,103,047,552$ \\
\hline 5 & 5 & 4 & 1 & $\$ 2,100,868,672$ \\
\hline 5 & 5 & 4 & 2 & $\$ 2,085,439,298$ \\
\hline 5 & 5 & 4 & 3 & $\$ 2,103,231,511$ \\
\hline 5 & 5 & 4 & 4 & $\$ 2,109,389,602$ \\
\hline 5 & 6 & 1 & 1 & $\$ 2,116,584,631$ \\
\hline 5 & 6 & 1 & 2 & $\$ 2,097,177,451$ \\
\hline 5 & 6 & 1 & 3 & $\$ 2,118,947,470$ \\
\hline 5 & 6 & 1 & 4 & $\$ 2,125,105,561$ \\
\hline 5 & 6 & 2 & 1 & $\$ 2,116,560,655$ \\
\hline 5 & 6 & 2 & 2 & $\$ 2,097,153,475$ \\
\hline 5 & 6 & 2 & 3 & $\$ 2,118,923,494$ \\
\hline 5 & 6 & 2 & 4 & $\$ 2,125,081,585$ \\
\hline 5 & 6 & 3 & 1 & $\$ 2,123,542,622$ \\
\hline 5 & 6 & 3 & 2 & $\$ 2,104,135,442$ \\
\hline 5 & 6 & 3 & 3 & $\$ 2,125,905,461$ \\
\hline 5 & 6 & 3 & 4 & $\$ 2,132,063,552$ \\
\hline 5 & 6 & 4 & 1 & $\$ 2,129,884,672$ \\
\hline 5 & 6 & 4 & 2 & $\$ 2,110,477,492$ \\
\hline 5 & 6 & 4 & 3 & $\$ 2,132,247,511$ \\
\hline 5 & 6 & 4 & 4 & $\$ 2,138,405,602$ \\
\hline 5 & 7 & 1 & 1 & $\$ 2,103,558,631$ \\
\hline 5 & 7 & 1 & 2 & $\$ 2,086,791,457$ \\
\hline 5 & 7 & 1 & 3 & $\$ 2,105,921,470$ \\
\hline 5 & 7 & 1 & 4 & $\$ 2,112,079,561$ \\
\hline 5 & 7 & 2 & 1 & $\$ 2,103,534,655$ \\
\hline 5 & 7 & 2 & 2 & $\$ 2,086,767,481$ \\
\hline 5 & 7 & 2 & 3 & $\$ 2,105,897,494$ \\
\hline 5 & 7 & 2 & 4 & $\$ 2,112,055,585$ \\
\hline
\end{tabular}


TABLE B.1 (Cont.)

\begin{tabular}{|c|c|c|c|c|}
\hline $\begin{array}{l}\text { Marketing } \\
\text { Alternative }\end{array}$ & $\begin{array}{c}\text { Glen Canyon } \\
\text { Operational } \\
\text { Scenario } \\
\end{array}$ & $\begin{array}{c}\text { Flaming Gorge } \\
\text { Operational } \\
\text { Scenario } \\
\end{array}$ & $\begin{array}{c}\text { Aspinall } \\
\text { Operational } \\
\text { Scenario } \\
\end{array}$ & $\begin{array}{c}\text { SPASM Estimates } \\
\text { of Wholesale } \\
\text { Power Costs }\end{array}$ \\
\hline 5 & 7 & 3 & 1 & $\$ 2,110,516,622$ \\
\hline 5 & 7 & 3 & 2 & $\$ 2,091,109,442$ \\
\hline 5 & 7 & 3 & 3 & $\$ 2,112,879,461$ \\
\hline 5 & 7 & 3 & $4^{\circ}$ & $\$ 2,119,037,552$ \\
\hline 5 & 7 & 4 & 1 & $\$ 2,116,858,672$ \\
\hline 5 & 7 & 4 & 2 & $\$ 2,097,451,492$ \\
\hline 5 & 7 & 4 & 3 & $\$ 2,119,221,511$ \\
\hline 5 & 7 & 4 & 4 & $\$ 2,125,379,602$ \\
\hline 6 & 1 & 1 & 1 & $\$ 2,017,893,408$ \\
\hline 6 & 1 & 1 & 2 & $\$ 2,008,070,389$ \\
\hline 6 & 1 & 1 & 3 & $\$ 2,019,115,516$ \\
\hline 6 & 1 & 1 & 4 & $\$ 2,022,242,160$ \\
\hline 6 & 1 & 2 & 1 & $\$ 2,017,869,432$ \\
\hline 6 & 1 & 2 & 2 & $\$ 2,008,046,413$ \\
\hline 6 & 1 & 2 & 3 & $\$ 2,019,091,540$ \\
\hline 6 & 1 & 2 & 4 & $\$ 2,022,218,184$ \\
\hline 6 & 1 & 3 & 1 & $\$ 2,021,416,045$ \\
\hline 6 & 1 & 3 & 2 & $\$ 2,011,593,026$ \\
\hline 6 & 1 & 3 & 3 & $\$ 2,022,638,152$ \\
\hline 6 & 1 & 3 & 4 & $\$ 2,025,764,796$ \\
\hline 6 & 1 & 4 & 1 & $\$ 2,024,634,649$ \\
\hline 6 & 1 & 4 & 2 & $\$ 2,014,811,630$ \\
\hline 6 & 1 & 4 & 3 & $\$ 2,025,856,756$ \\
\hline 6 & 1 & 4 & 4 & $\$ 2,028,983,400$ \\
\hline 6 & 2 & 1 & 1 & $\$ 2,019,846,780$ \\
\hline 6 & 2 & 1 & 2 & $\$ 2,010,023,761$ \\
\hline 6 & 2 & 1 & 3 & $\$ 2,021,068,888$ \\
\hline 6 & 2 & 1 & 4 & $\$ 2,024,195,532$ \\
\hline 6 & 2 & 2 & 1 & $\$ 2,019,822,804$ \\
\hline 6 & 2 & 2 & 2 & $\$ 2,009,999,785$ \\
\hline 6 & 2 & 2 & 3 & $\$ 2,021,044,912$ \\
\hline 6 & 2 & 2 & 4 & $\$ 2,024,171,556$ \\
\hline
\end{tabular}


TABLE B.1 (Cont.)

\begin{tabular}{|c|c|c|c|c|}
\hline $\begin{array}{l}\text { Marketing } \\
\text { Alternative }\end{array}$ & $\begin{array}{c}\text { Glen Canyon } \\
\text { Operational } \\
\text { Scenario } \\
\end{array}$ & $\begin{array}{c}\text { Flaming Gorge } \\
\text { Operational } \\
\text { Scenario } \\
\end{array}$ & $\begin{array}{c}\text { Aspinall } \\
\text { Operational } \\
\text { Scenario } \\
\end{array}$ & $\begin{array}{c}\text { SPASM Estimates } \\
\text { of Wholesale } \\
\text { Power Costs }\end{array}$ \\
\hline 6 & 2 & 3 & 1 & $\$ 2,023,369,416$ \\
\hline 6 & 2 & 3 & 2 & $\$ 2,013,546,397$ \\
\hline 6 & 2 & 3 & 3 & $\$ 2,024,591,524$ \\
\hline 6 & 2 & 3 & 4 & $\$ 2,027,718,168$ \\
\hline 6 & 2 & 4 & 1 & $\$ 2,026,588,020$ \\
\hline 6 & 2 & 4 & 2 & $\$ 2,016,765,002$ \\
\hline 6 & 2 & 4 & 3 & $\$ 2,027,810,128$ \\
\hline 6 & 2 & 4 & 4 & $\$ 2,030,936,772$ \\
\hline 6 & 3 & 1 & 1 & $\$ 2,060,006,456$ \\
\hline 6 & 3 & 1 & 2 & $\$ 2,040,599,276$ \\
\hline 6 & 3 & 1 & 3 & $\$ 2,062,369,295$ \\
\hline 6 & 3 & 1 & 4 & $\$ 2,068,527,386$ \\
\hline 6 & 3 & 2 & 1 & $\$ 2,059,982,480$ \\
\hline 6 & 3 & 2 & 2 & $\$ 2,040,575,300$ \\
\hline 6 & 3 & 2 & 3 & $\$ 2,062,345,319$ \\
\hline 6 & 3 & 2 & 4 & $\$ 2,068,503,410$ \\
\hline 6 & 3 & 3 & 1 & $\$ 2,066,964,448$ \\
\hline 6 & 3 & 3 & 2 & $\$ 2,047,557,268$ \\
\hline 6 & 3 & 3 & 3 & $\$ 2,069,327,287$ \\
\hline 6 & 3 & 3 & 4 & $\$ 2,075,485,378$ \\
\hline 6 & 3 & 4 & 1 & $\$ 2,073,306,497$ \\
\hline 6 & 3 & 4 & 2 & $\$ 2,053,899,317$ \\
\hline 6 & 3 & 4 & 3 & $\$ 2,075,669,336$ \\
\hline 6 & 3 & 4 & 4 & $\$ 2,081,827,427$ \\
\hline 6 & 4 & 1 & 1 & $\$ 2,064,211,138$ \\
\hline 6 & 4 & 1 & 2 & $\$ 2,044,803,958$ \\
\hline 6 & 4 & 1 & 3 & $\$ 2,066,573,977$ \\
\hline 6 & 4 & 1 & 4 & $\$ 2,072,732,068$ \\
\hline 6 & 4 & 2 & 1 & $\$ 2,064,187,162$ \\
\hline 6 & 4 & 2 & 2 & $\$ 2,044,779,982$ \\
\hline 6 & 4 & 2 & 3 & $\$ 2,066,550,001$ \\
\hline 6 & 4 & 2 & 4 & $\$ 2,072,708,092$ \\
\hline
\end{tabular}


TABLE B.1 (Cont.)

\begin{tabular}{|c|c|c|c|c|}
\hline $\begin{array}{l}\text { Marketing } \\
\text { Alternative }\end{array}$ & $\begin{array}{c}\text { Glen Canyon } \\
\text { Operational } \\
\text { Scenario } \\
\end{array}$ & $\begin{array}{c}\text { Flaming Gorge } \\
\text { Operational } \\
\text { Scenario } \\
\end{array}$ & $\begin{array}{c}\text { Aspinall } \\
\text { Operational } \\
\text { Scenario } \\
\end{array}$ & $\begin{array}{c}\text { SPASM Estimates } \\
\text { of Wholesale } \\
\text { Power Costs }\end{array}$ \\
\hline 6 & 4 & 3 & 1 & $\$ 2,071,169,130$ \\
\hline 6 & 4 & 3 & 2 & $\$ 2,051,761,950$ \\
\hline 6 & 4 & 3 & 3 & $\$ 2,073,531,969$ \\
\hline 6 & 4 & 3 & 4 & $\$ 2,079,690,060$ \\
\hline 6 & 4 & 4 & 1 & $\$ 2,077,511,179$ \\
\hline 6 & 4 & 4 & 2 & $\$ 2,058,103,999$ \\
\hline 6 & 4 & 4 & 3 & $\$ 2,079,874,018$ \\
\hline 6 & 4 & 4 & 4 & $\$ 2,086,032,109$ \\
\hline 6 & 5 & 1 & 1 & $\$ 2,092,669,403$ \\
\hline 6 & 5 & 1 & 2 & $\$ 2,073,262,223$ \\
\hline 6 & 5 & 1 & 3 & $\$ 2,095,032,242$ \\
\hline 6 & 5 & 1 & 4 & $\$ 2,101,190,333$ \\
\hline 6 & 5 & 2 & 1 & $\$ 2,092,645,427$ \\
\hline 6 & 5 & 2 & 2 & $\$ 2,073,238,247$ \\
\hline 6 & 5 & 2 & 3 & $\$ 2,095,008,266$ \\
\hline 6 & 5 & 2 & 4 & $\$ 2,101,166,357$ \\
\hline 6 & 5 & 3 & 1 & $\$ 2,099,627,394$ \\
\hline 6 & 5 & 3 & 2 & $\$ 2,080,220,214$ \\
\hline 6 & 5 & 3 & 3 & $\$ 2,101,990,233$ \\
\hline 6 & 5 & 3 & 4 & $\$ 2,108,148,324$ \\
\hline 6 & 5 & 4 & 1 & $\$ 2,105,969,444$ \\
\hline 6 & 5 & 4 & 2 & $\$ 2,086,562,264$ \\
\hline 6 & 5 & 4 & 3 & $\$ 2,108,332,283$ \\
\hline 6 & 5 & 4 & 4 & $\$ 2,114,490,374$ \\
\hline 6 & 6 & 1 & 1 & $\$ 2,121,685,403$ \\
\hline 6 & 6 & 1 & 2 & $\$ 2,102,278,223$ \\
\hline 6 & 6 & 1 & 3 & $\$ 2,124,048,242$ \\
\hline 6 & 6 & 1 & 4 & $\$ 2,130,206,333$ \\
\hline 6 & 6 & 2 & 1 & $\$ 2,121,661,427$ \\
\hline 6 & 6 & 2 & 2 & $\$ 2,102,254,247$ \\
\hline 6 & 6 & 2 & 3 & $\$ 2,124,024,266$ \\
\hline 6 & 6 & 2 & 4 & $\$ 2,130,182,357$ \\
\hline
\end{tabular}


TABLE B.1 (Cont.)

\begin{tabular}{|c|c|c|c|c|}
\hline $\begin{array}{l}\text { Marketing } \\
\text { Alternative }\end{array}$ & $\begin{array}{c}\text { Glen Canyon } \\
\text { Operational } \\
\text { Scenario } \\
\end{array}$ & $\begin{array}{c}\text { Flaming Gorge } \\
\text { Operational } \\
\text { Scenario } \\
\end{array}$ & $\begin{array}{c}\text { Aspinall } \\
\text { Operational } \\
\text { Scenario } \\
\end{array}$ & $\begin{array}{c}\text { SPASM Estimates } \\
\text { of Wholesale } \\
\text { Power Costs }\end{array}$ \\
\hline 6 & 6 & 3 & 1 & $\$ 2,128,643,394$ \\
\hline 6 & 6 & 3 & 2 & $\$ 2,109,236,214$ \\
\hline 6 & 6 & 3 & 3 & $\$ 2,131,006,233$ \\
\hline 6 & 6 & 3 & 4 & $\$ 2,137,164,324$ \\
\hline 6 & 6 & 4 & 1 & $\$ 2,134,985,444$ \\
\hline 6 & 6 & 4 & 2 & $\$ 2,115,578,264$ \\
\hline 6 & 6 & 4 & 3 & $\$ 2,137,348,283$ \\
\hline 6 & 6 & 4 & 4 & $\$ 2,143,506,374$ \\
\hline 6 & 7 & 1 & 1 & $\$ 2,108,659,403$ \\
\hline 6 & 7 & 1 & 2 & $\$ 2,089,252,223$ \\
\hline 6 & 7 & 1 & 3 & $\$ 2,111,022,242$ \\
\hline 6 & 7 & 1 & 4 & $\$ 2,117,180,333$ \\
\hline 6 & 7 & 2 & 1 & $\$ 2,108,635,427$ \\
\hline 6 & 7 & 2 & 2 & $\$ 2,089,228,247$ \\
\hline 6 & 7 & 2 & 3 & $\$ 2,110,998,266$ \\
\hline 6 & 7 & 2 & 4 & $\$ 2,117,156,357$ \\
\hline 6 & 7 & 3 & 1 & $\$ 2,115,617,394$ \\
\hline 6 & 7 & 3 & 2 & $\$ 2,096,210,214$ \\
\hline 6 & 7 & 3 & 3 & $\$ 2,117,980,233$ \\
\hline 6 & 7 & 3 & 4 & $\$ 2,124,138,324$ \\
\hline 6 & 7 & 4 & 1 & $\$ 2,121,959,444$ \\
\hline 6 & 7 & 4 & 2 & $\$ 2,102,552,264$ \\
\hline 6 & 7 & 4 & 3 & $\$ 2,124,322,283$ \\
\hline 6 & 7 & 4 & 4 & $\$ 2,130,480,374$ \\
\hline
\end{tabular}




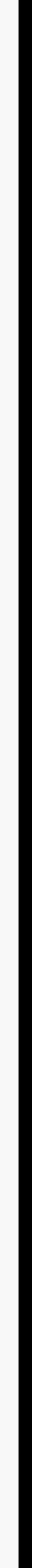

